\title{
IDENTIFYING LEAD MARKETS FOR THE INTERNATIONAL BANKNOTE PRODUCTION INDUSTRY
}

\author{
G. V. KORNILOV \\ Research Institute of Goznak, Russia ${ }^{a}$
}

A. V. TRACHUK

Higher School of Management, Financial University under the Government

of the Russian Federation, Russia ${ }^{b}$

This paper contributes to theoretical study of innovation diffusion by exploring a role of lead markets factor for innovation adoption at international markets of products and technologies for national security. The study is based on data obtained from analysis of innovations in banknote production industry. The international banknote industry characterized by limited number of buyers (monopsony) and suppliers (oligopoly) is an example of highly innovative sector with important national security task to maintain integrity of currency circulation. It is a truly global industry focused on constant development of new security technologies adopted by most of the central banks. Our findings suggest the factor of lead market is one of the key elements in taking decision by the central bank to adapt certain security features and technologies for their banknotes. Geographical origination of a particular technology is been put aside when issue of national security is in place. Only the value of an innovation itself matters. We argue that lead market factor is a specific characteristic for of innovation diffusion in this sector that should be common for areas where government institutions act as single buyer when the supply is scarce i.e. military industry, space sector, some pharmaceutical markets etc.

Keywords: lead markets, banknote industry, national security, diffusion of innovations, currency circulation.

JEL: G21, H76, L69, O33.

Postal Addresses: a 19, Mytnaya ul., Research Institute of Goznak, Moscow, 115162, Russia; b 49, Leningradsky Pr., Higher School of Management, Financial University under the Government of the Russian Federation, Moscow, 125993, Russia.

(C) G. Kornilov, A. Trachuk, 2020

https://doi.org/10.21638/spbu18.2020.402 


\section{INTRODUCTION}

The development of an effective system for searching, selecting and implementing innovations for national security is the subject of a number of studies [Mowery, 2009; Gansler, 2016; Iles et al., 2017]. Such studies focus on the role of state institutions in promoting innovative activity in socially or politically meaningful areas. One of the features of the markets, where state institutions are the customers or final buyers, is that the number of players in such markets is often limited. The situation is common, for example, for the public health sector [Kirkwood, 2016], the environmental protection [Jog, Kosmopoulou, 2014], the national security and defence [Mahoney, 2017], and space exploration [Szajnfarber, Richards, Weigel, 2014], i.e. when it comes to products or solutions that the state needs to provide public or quasi-public goods and services to its citizen. Many states realize cautious and responsible strategy of procurement to obtain products that have already been tested by some other consumers [Linton, 2018].

Adopting innovative products and technologies is an important condition for achieving the state's objectives: providing new opportunities to create public goods or reducing costs to create them, as well as implementing ground-breaking projects earlier than in other countries improves infrastructure quality and, consequently, the country's competitiveness and welfare of its people. Public procurement markets are typically dominated by a single buyer (monopsony) and very often by a limited number of sellers (oligopoly), which would impose speciality on the innovation diffusion processes.

There are also other, much less explored, spheres of state interests. Among these is currency circulation. States (central banks) spend more than US $\$ 10$ bln annually on banknote production alone [Pizzanelli, 2011]. These expenditures include, inter alia, research and development to protect banknotes against counterfeiting. Development of banknotes and anti-counterfeit security features, as it will be shown in this study, is one of the most innovative branches of modern printing. Increase of counterfeit banknotes in circulation and subsequent loss of reliability (higher probability of receiving a counterfeit banknote) may disorganize payment system as a whole and also undermine integrity of the national currency [FATF, 2013].

The global technological trend of digitalization has influenced currency circulation. Recently the central banks of most of countries got themselves involved into discussions on using Central Bank Digital Currencies (CBDC) that at some point of time should change payment landscape by eliminating or supplementing presently existing payment instruments [Barrdear, Kumhof, 2016; Ketterer, 2016; Digital Ruble, 2020]. However at present cash is still the most preferred payment instrument globally and the task of keeping its integrity by providing physical security is one of the main concerns of all issuing authorities.

All states face similar challenges in the sphere of currency circulation regardless of their economic situation and level of macroeconomic stability, since these risks are largely technological in nature (degree of development and level of penetration of certain technologies, availability of specific materials or their substitutes, etc.). However, not all the countries have a mature system for developing and implementing innovations designed to protect banknotes against counterfeiting; moreover some countries do not have the resources to produce their own banknotes. We assume that a mechanism for searching and selecting innovations in banknote industry ensuring that the banknotes produced are properly protected against counterfeiting and modernized in a timely manner to reflect technological changes and other external factors is already in place.

Certain geographical markets in different fields become the lead markets, that is, markets where the adoption of innovations precedes their global diffusion [Beise, 2001]. We assume as in the case of consumer innovation diffusion, when adopting an innova-

PЖM 18 (4): 497-524 (2020) 
tion for use in banknote production, state institutions (or their authorized agents) are guided by innovative solutions that have already been introduced and proved their effectiveness in other countries.

In this paper, we examine the process of innovations diffusion in solutions and products for national security applications by using banknote production as an example. In doing so, we will attempt to prove the hypothesis that there are also lead markets for such solutions, where the adoption of innovations takes place before such innovative products and solutions become dominant globally. On the one hand, the confirmation of this hypothesis will allow product developers in such markets to choose a strategy that focuses on the promotion of their products in lead markets, and on the other hand, state institutions and central banks that purchase such products and solutions would be able to manage their resources more effectively. The results should also be relevant to companies in sectors that focus on products and services consumed by governments or government agencies for example medicine and in particular marketing of new vaccine. It will allow them to focus their effort on specific market saving investments and understanding that it will be sufficient to gain wide international reputation.

\section{THEORETICAL REVIEW}

Modern concepts of the diffusion of innovations were developed mainly by analysing how buyers perceived innovations in consumer goods markets, where many potential buyers are ready to adopt (or not) these innovations. The diffusion of innovations relates to the technical readiness to adopt them and an innovation culture; no less important is the role played by the imitation of others' behaviour when other consumers decide to adopt an innovation [Von Hippel, 1986].

E. Rogers suggested studying innovations in context of their adoption by in- dividuals [Rogers, 2003]. Later, this approach was widely used in research and practice, and was developed in many other studies in relation to different consumer markets. Further studies showed that before an innovation is adopted, it is evaluated in terms of price/benefit [Fliegel, Kivlin, 1966; Deffuant, Huet, Amblard, 2005; Franke, Von Hippel, Schreier, 2006; Hafeez, Hooi Keoy, Hanneman, 2006; Straub, 2009]. However, the consumer's decision to adopt an innovation is not based on this evaluation only. Important factors in the diffusion of innovation include the so-called "lead users" who are ahead of the market in terms of needs, motivation and qualifications [Urban, Von Hippel, 1988; Morrison, Roberts, Von Hippel, 2000; Lüthje, Herstatt, 2004; Bilgram, Brem, Voigt, 2008]. Lead users create an innovation diffusion environment.

The main characteristic of an innovation is that it must be significantly different from existing products supplied by the company. The innovations could be categorized by novelty and market impact. The most common classification include incremental, radical and disruptive innovations. However other types of innovations are identified by some authors [Henderson, Clark, 1990].

A classic view suggests that market transactions are the fundamental drivers of innovations. Innovations occur through the interaction of user needs (market pull) and seller capabilities (product push) [Rothwell, 1994]. In a market where there are several independent buyers and sellers, interaction of this kind happens naturally.

However, in a market with only one buyer (monopsony), a different type of interaction takes place. Moreover, when it comes to niche markets such as markets for solutions and products for national security, there are only a few sellers (oligopoly), and normal market interaction leading to continuous product improvement and generation of incremental innovations in the course of everyday interaction between sellers and buyers is extremely limited. In a certain 
sense, it is replaced by a practice where suppliers involve individual buyers in joint work and discussion of development results, or end buyers organize the development of specific solutions using the capabilities of both potential suppliers in the market and the national innovation system [Nelson, 1993]. Therefore, demand characteristics, to some extent, serve as an explanation for supply characteristics. In this case, procurement policy is a more effective tool for stimulating innovation than directly subsidizing research and development [Geroski, 1990].

In these conditions, the innovation and diffusion process gains some specific particularities. These first of all include the dominant role of supply, i.e. use of earlier innovation models - the technology-push model.

Examples of markets with monopsony consumption and oligopoly supply include the aerospace market [Szajnfarber, Richards, Weigel, 2014], the arms market [Mahoney, 2017], and some segments of the pharmaceutical market [Kirkwood, 2016]. Problems related to stimulating new developments, selecting and disseminating innovations in these markets are similar. The banknote production market can also be rightfully included in this list [Trachuk, Kornilov, $2013 \mathrm{~b}$. The goal of state institutions working in such markets is to enable the maximum number of potential suppliers to offer products and solutions that allow the state to tackle its tasks more effectively.

However, there are situations when offthe-shelf solutions are not available or cannot be used due to existing constraints of different nature. In this case, it is fundamental for the buyer to be able to create the required product using the potential of the national innovation system and international cooperation. However, it is not at all obvious that such a product or solution can have significant market potential in other markets. This kind of behaviour of single buyers is, however, peculiar to countries with a developed innovation ecosystem, and in this case the supply will be influenced both by suppliers' offerings and by factors such as ties between business and science and the relationships between producers (e.g. [Lundvall, 1992; Nelson, 1993; 1995; Malerba, 2006]). It should be noted that in both variants, the selection of an innovation is effected by the very limited number of options available to the buyer. This determines the oligopolistic nature of supply.

Given that the buyers are state institutions, they are obviously inclined to take fewer risks than business entities. Therefore, the adoption of innovations by such institutions is usually based on a certain number of references - experience and feedback provided by other similar buyers from other countries or wide testing in real or close to real conditions.

Based on previously published works and ideas that we have formulated, the creation and diffusion of innovations in single-buyer markets have the following features: (1) limited number of offerings (supplier oligopoly); (2) importance of validating information on the effectiveness of the new solution. In such cases, effectiveness is usually validated through the end buyer's own product testing or the experience of such consumers in other countries.

To explain some of the innovation adoption patterns on the demand side of a singlebuyer market, we believe that the concept of lead markets may be of considerable interest. The concept introduces the notion of lead markets in the context of geographical markets. In accordance with this concept, innovations are introduced in certain countries before they have been widely adopted, subsequently becoming a global standard [Cleff, Grimpe, Rammer, 2007].

A lead market can be defined as the geographical starting point of global diffusion processes [Beise, Rennings, 2005]. The characteristics of lead markets are always related to a particular industry; a country can be a lead market in one industry and a lag market in another one. Firms that develop products for lead markets benefit from introducing innovations on a global level. At the same time, 
lead markets can benefit from attracting companies from abroad that seek to launch innovations in the lead market in order to obtain information for global advancement.

The concept of lead markets as a tool for analysing the differences in innovation activity in individual countries was suggested by M. Beise [Beise, 2001; 2004; 2006]. This concept was successfully used by some firms to organize new product development [Beise, Cleff, 2004]. Later, the application of the concept was extended to a sector level, in particular, the automotive industry [Cleff, Grimpe, Rammer, 2015] and country [Herstatt, Tiwari, 2016] or economic union level [European Commission, 2007]. However, if it was found practical for such narrow market as for example fish farming [Nijssen et al., 2019]. Then, the concept was extended to other industries [Rennings, Smidt, 2010; Quitzow et al., 2014] and applied to innovation diffusion in emerging economies [Tiwari, Herstatt, 2012].

The purpose of this article is to prove the hypothesis that single-buyer markets with a limited number of sellers (monopsony-oligopoly market), including markets for solutions and products needed for national security, where the state (or its institutions) acts as the buyer, have certain mechanisms for diffusing innovations that are inherent to the consumer market. Many innovation adoption features can be explained by imitative behaviour, when the buyer state (or its agent) starts to use innovations based on their adoption by other markets. In the global market environment, it is possible to identify regional markets (individual countries) that will become leaders for individual products. Innovations will be adopted in such markets before global adoption.

The diffusion of innovations will be considered by using the international banknote production market as an example. We apply quantitative analysis to identify the existence of lead markets and evaluate their significance.

The results of this study should provide additional insight into the factors that in- fluence innovation activity in the banknote production market, and also create a tool to identify the markets that represent the greatest potential for promoting new solutions with a potential for further global diffusion.

\section{METHODS}

We argue that when a single state buyer decides on purchasing innovative products, it will focus on experience in the introduction of such products in other markets, which will be "lead markets" for the sector being studied. The concept of lead markets that looks at the market from the supply-side should allow us to explain regularities in the diffusion of global innovations better than concepts based on an analysis limited to innovative offerings only.

In the study of the diffusion of innovations in markets where the state is the buyer, we should identify "lead markets" where innovations appear before, and facilitate, global diffusion. This identification is based on the assumption that there are country markets that were the first to adopt innovative technologies and solutions, which were subsequently diffused globally, in a sustainable manner during a long period of time.

Contemporary studies presents approaches to assess "leadership" potential of markets in order to predict which geographical market will become the leader for a particular product or technology [Beise, 2004; Beise, Cleff, 2004]. This approach is based on identifying five characteristics inherent to a lead market. For these purposes it is necessary to identify a set of variables (indicators) that reflect specific economic indicators for each characteristic inherent to a lead market. This is an indicator approach. It is based on detailed knowledge of the products, their potential consumers and their performance characteristics. This knowledge is used to develop individual indicators that can be measured in differ- 
ent country markets. These indicators are used to construct a consolidated index characterizing the potential of the country's lead market for individual products. In a number of cases, the indicator method is combined with the survey method (interview of industry leaders) [Cleff, Grimpe, Rammer, 2015]. We find this approach applicable but very time and energy consuming and tried to offer less data and expertise sensitive method to identify lead markets. Our empirical research data is taken from information about the global banknote production market gathered during our study. Our analysis will use data characterizing the geographical and temporal diffusion of new technologies in the sector. The results should indicate individual countries or groups of countries, which were the first to start using technologies that later diffused globally. Next, we will identify the countries that are the source of innovations in the sector. These data will be compared with data on countries leading in implementation. Thus, we intend to formulate a model for the diffusion of innovations.

It is assumed that the behaviour of lead countries is similar to the behaviour of lead users in the consumer market. Lead users are faced with new needs earlier than other consumers in the market [Von Hippel, 1986]. The diffusion of innovations in lead markets precedes their global diffusion [Beise, 2001]. The general picture of the diffusion of innovations in the international market will be similar to the diffusion of innovations in the consumer goods market as described by E. Rogers [Rogers, 2003], that is, there are innovating countries and early adopting countries in the international market, which are the first to introduce a new product or technology. In the event that a product or technology is widely diffused in these countries after it has been introduced, then such markets become lead markets.

The subject of our study is a market with monopsony buyers and an oligopolistic supply. The banknote production market can be rightly considered to be such a market: being the only buyer, the state (central bank) is limited in its choice of suppliers. Furthermore, the need to protect the currency circulation against counterfeiting requires constant development and implementation of new security technologies.

To test the hypothesis regarding the importance of orientation towards "leaders" in diffusing innovations in public markets, we present an approach based on a quantitative analysis of the adoption of new products and solutions, as well as an evaluation of how quickly they are diffused in the international market - adoption of innovations by individual countries.

The subject of this study is the diffusion of innovations in the international banknote production market. Banknote production rarely comes into view of economic researchers. However, the information base for studying the banknote market is quite extensive: banknote production market research [Pizzanelli, 2011], specialized publications, banknote market news ${ }^{1}$ and Internet resources $^{2}$. There are several industry conferences that attract leading experts specializing in banknotes and currency circulation. Central banks, banknote manufacturers and external authors publish their studies on how banknotes are perceived by the public and ways to protect banknotes from counterfeiting [van Renesse, 1998; De Hej, 2009; Bonnell, 2010]. There are also studies on the history of the banknote manufacturing industry [Bender, 2006]. However, in some cases, banknote production may involve national security issues, so not all data are publicly available, but an accessible set of

\footnotetext{
${ }^{1}$ For example: Currency News. Monthly bulletin published by Currency Publication Ltd. since 2002; Infosecure. Newsletter published by Intergtaf (European Federation for Print and Digital Communication); Billetaria. International review of cash management published by the Bank of Spain.

${ }^{2}$ For example: (1) Banknote Industry News. URL: https://www.banknote-industry-news.com/; (2) Banker's Guide to Foreign Currency and Coins. URL: http://www.banknotestreet.com (accessed: 01.06.2020).
} 
data is quite sufficient for the purposes of this study.

The most common innovation characteristic for banknote production is the use of new security features, which are designed to make counterfeit and imitation highly difficult. We believe that by analysing processes and the diffusion of new security features, we will be able to trace the innovation diffusion dynamics in this sector.

Banknote production market is well established and the dominant product design is widely accepted. The market was disrupted several times in last few decades by introduction of cashless payment methods and innovative payment instruments (payment cards, e-money, cyber currencies, central bank digital currency etc.) that have led to formation of new markets. However so far all this radical innovations have little effect on banknote market in terms of its volume [Trachuk, Golembiovsky, 2012]. The incremental innovations meet the challenges posed by modern technologies and new payment environment and allow keeping the dominant design intact.

Modern innovations in different areas are often associated with process of digitalization implying that use of digital technologies lead to change of business model and provide new revenue. Accelerating utilization of digital technologies is one of the trends in the banknote industry. However today it mostly effects designing and production processes enabling to minimize time to market. These innovations are common for any industrial processes and in particular for the printing industry. The core innovations of banknote industry are associated with introduction of new security features and indirectly related to digital products.

Security innovations allow central banks and law enforcement agencies to confront the counterfeiting threat. It is namely the counterfeiting threat that is believed to stimulate the development and adoption processes related to new security features.

Given that basic materials and processes used in banknote production are similar, the security features and design constitute the main differences between banknotes issued by different countries and manufacturers. The competition between banknote manufacturers and material suppliers is played out in the field of security features that provide maximum protection at an affordable price [Trachuk, Kornilov, 2013b]. Suppliers of equipment and materials are the main suppliers of innovations in this industry [Pizzanelli, 2011].

Despite a great variety of banknotes, the number of security features used on them is limited. Some security elements and technologies have become an industry standard and are used on most banknotes. Others, appearing on the banknotes of one or several countries, are not further diffused. Finally, the third group of security elements was actually developed, but never applied.

Study began with identification and description of specific innovations, whose diffusion can be tracked on a global scale. It should be noted that, due to advancement in copying equipment and changes in printing technology, banknote manufacturers are forced to constantly develop and launch new security features on the market, and regularly make changes to the banknote security. Therefore, to accomplish the tasks of this study, we selected innovative security features used in banknote production, which are designed to protect against copying and duplication, as a product that should be approved by customers. It is important to underline the fact that the choice of a specific set of security features in a banknote and, consequently, the decision to adopt an innovation, is the prerogative of the customer, while the situation when the banknote manufacturer uses features developed by another company is very common.

The study period should be long enough to cover more than a few modernization (update) cycles for banknotes and find out how the innovations were adopted in this market. A 20-year period would be sufficient to allow analysis of innovations in the banknote market. In banknote production, changes 
(updates) to banknotes usually occur approximately every 7-10 years. However, the lifespan of security features can significantly exceed this period [De Hej, 2010]. In order to obtain meaningful results, the study period covered several cycles of banknote design changes. This enabled us not just to single out a market that was the first to introduce a specific innovation, but also to identify sustainability with regard to leadership of individual countries in implementing innovations.

During our study, we were able to determine the exact period of innovation implementation. This data is available for all markets. In the case of the banknote market, this is the time it took to put new banknotes into circulation, which is publicly available information.

Geographically, our study covers the widest possible market. The goal is to analyse the behaviour of state institutions (central banks) as buyers in terms of adopting innovations. The banknote market is completely global and monopsonical for each country market.

A national or regional market can act as the lead market [Cleff, Grimpe, Rammer, 2015]. Therefore markets identified on the basis of quantitative analysis and the first to implement innovations can be grouped by technology-borrowing approach, having formed clusters using a set of similar innovations. This will allow us, on the one hand, to test the hypothesis of the existence of multinational lead markets, and on the other hand, to determine whether there is a link between lead markets in terms of adopting innovations and technology lead countries, where innovation developers are located.

The analysis of data on innovation diffusion allows classifying countries by their position on the innovation adoption curve: from innovators to laggards. If individual markets are regularly classified as innovators or early adopters, they can be regarded as lead markets. However, one condition must be fulfilled, namely, that once the innovation was adopted by the countries, it was dif- fused further, i.e. was adopted by the early and late majority. The fact that the market adopts innovations early and regularly, where these innovations are not diffused any further, does not constitute evidence that such market is a lead market.

The analysis was based on objective data on banknote issuance by central banks of all countries. The data source was the industry database on banknotes issued around the world with a description of their security features, intended for law enforcement officers and banknote manufacturers [International Banknote Designers Association, 2018]. The data were additionally checked through central banks of individual countries.

We chose a time period from 1996 to 2017. On the one hand, this period saw a paradigm shift in the field of banknote security (start of extensive use of elements that provide security against imitation made with digital copying devices), and on the other hand, a change in at least several generations of banknotes in each country, thus allowing us to see dynamics over time. The scope of our study covered all countries that issued banknotes or were members of currency unions in this period, i. e. a total of 177 countries.

Based on the frequency of use, we identified 31 security features and technologies for the analysis. They included both features used at the beginning of the study and features that appeared and were diffused later. The systematization of security features used in banknote production allowed us to divide them into groups based on manufacturing techniques: optically variable materials, holograms, substrates, security threads (according to width and visual effect), transparent windows, and printing features. The breakdown of features and technologies by group is presented (Appendix, Table 1).

Information on banknotes issued around the world was gathered into a single database, which contained the following information for each banknote: the issuing country, the denomination, the year when circulation ended, the year the banknote was withdrawn from circulation, and a list of security features.

PЖM 18 (4): 497-524 (2020) 
As a matter of convenience, the banknotes were grouped by denomination - high, medium and low. The two largest denominations were listed in the high denomination group, and the two lowest in the low denomination group. The remaining banknotes were listed as medium denominations. The need to group banknotes by denomination was due to the fact that banknotes of different denominations are designed using different approaches. In particular, high-denomination banknotes have more security features, and more expensive features are used on them more often. Supplementary information in the database included information on GDP per capita for each country that issued banknotes, the geographical location of the country (part of the world), and the availability of banknote production in the country.

One parameter, the year when circulation ended, should be discussed additionally. Different countries follow a different policy for withdrawing banknotes from circulation: from withdrawing old series from circulation to unlimited parallel circulation of all banknote series issued. In our study, it is important to consider when the innovation started to be used and its geographical diffusion. Therefore, the year when circulation ended was defined as the year when an updated or new banknote of a given denomination was issued. In this case, the old banknote could remain in circulation, but it is not used in statistics related to security features.

The result was a consolidated database created in MS Access software, which allowed us to analyse the diffusion of new security features in banknote production over the past 20 years. The database provided information on the number of security features used every year, in what denominations they prevailed, their ratio to the total number of issued banknotes, and their distribution by geographical location of countries and their GDP. Based on database materials, the following reports were generated: (1) the number of active banknotes incorporating a specific security feature; (2) the number of active banknotes incorporating a security feature with a division into high, medium and low denominations; (3) the number of issued banknotes per year incorporating a specific security feature versus the total number of banknotes issued in that year; (4) the total number of specific security features on active banknotes; (5) the number of banknotes with specific features by parts of the world; (6) the number of active banknotes with a security feature in countries with the same level of GDP per capita (over $\$ 64848, \$ 32424$ - $\$ 64$ 848, \$16 212 $\$ 32424, \$ 8106-\$ 16212, \$ 4053-$ $\$ 8106, \$ 2027-\$ 4053, \$ 1013-\$ 2027$, $\$ 507$ - $\$ 1013$, below $\$ 507)$.

After completing initial data analysis, we had to eliminate from further study several features and technologies that ether did not have mass diffusion or were already being widely used at the start of our study. Some features have the potential for mass diffusion, but did not acquire it by the end of the data collection period. As a result, 22 features and technologies were left for further analysis.

Quantitative models were constructed on the basis of available data for the diffusion of each innovation. Graphically, the model looked like a histogram, in which the number of countries that introduced new material or technology was shown on the vertical axis (Appendix, Table 2).

For example, Fig. 1 shows the diffusion of Motion micro-optic security threads supplied by the US company Crane Currency. For the first time the feature appeared on a banknote in 2006. For three first years it been used only on few banknotes around the world. Since the year 2009 it gained mass adoption after which its presence on banknotes only grow from year to year reaching 70 banknotes in 2016. Out of 103 new banknotes issued in 201618 banknotes featured Motion security thread. Motion is innovative and expensive security feature and it been used primarily at higher and middle denomination notes that require better protection (15 banknotes with Motion). That means that 


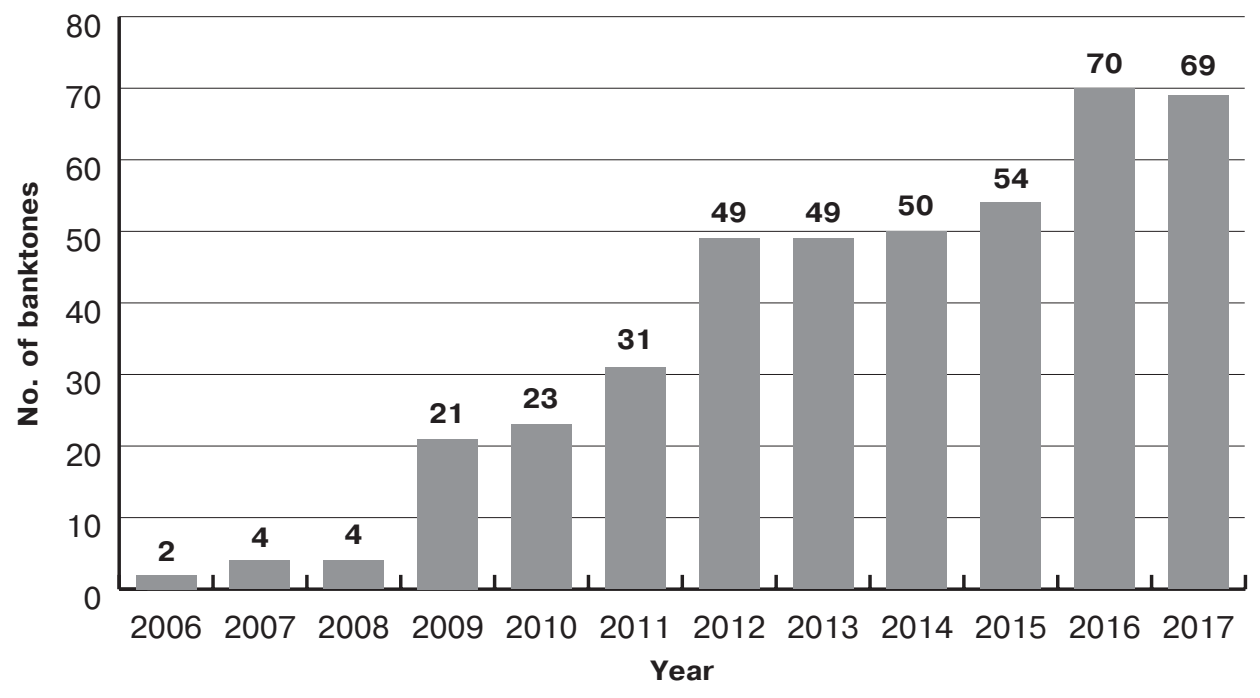

Fig. 1. Global adoption of Motion security thread by years

the security feature is a standard for higher and middle denomination notes.

This allowed us to distinguish the different stages in the adoption of innovations. Three stages were identified for the purpose of the study: (1) the start of usage of the innovation (first year); (2) the period preceding mass diffusion of the innovation (from the second year to the year preceding mass usage); and (3) the start of mass usage of the innovation. Usage of the feature (innovation) on more than 10 new banknotes per year, which corresponds to usage in at least 3-4 new countries, was taken as an indicator characterizing its mass usage in the banknote market. As for the cycle of changing the banknote series after 7 years, it means that this feature will be used on banknotes in at least 25 countries. In reality, the figure is much higher. In the case of the Motion security thread, it can be seen that the feature received mass usage in the fourth year after it was launched. However, after the first year of mass usage (17 new banknotes in 2009), the feature was widely diffused even further, and in 2016 it was used on 70 banknotes in different countries.

Statistical information was processed using the SPSS software: the number of times security features appeared on new banknotes was counted. Thus, we are able to indicate the countries that were the first to introduce new security features on their banknotes. The leading countries were brought into table for further analysis (Appendix, Table 2). Depending on how many times new features appeared on country's banknotes for the first time or within a period preceding to mass adoption, the country is placed higher in the table.

Additional analysis was implemented in accordance with the hierarchical cluster analysis methodology [Taganov, 2005]. Ward's method was used to form the clusters; squared Euclidean distance was chosen for determining the distance between interval variables [Rabinovich, 2007]. The difference between the clusters was calculated by the following formula:

$$
\mathrm{R}(\mathrm{W}, \mathrm{S})=\frac{|S||W|}{|S|+|W|} \rho^{2}\left(\sum_{\omega \in W} \frac{\omega}{|W|} \sum_{s \epsilon S} \frac{s}{|S|}\right),
$$

where $W$ - cluster formed by two the most proximate clusters; $S$ - any other cluster distance to which is to be calculated; $R$ - distance functions between clusters; $\rho$ - distance functions between objects; $\omega$, $s$ - objects of clusters $W$ and $S$. 
Fragment of clustering results

\begin{tabular}{c|c|c|c|c|c|c|c|c|c|c}
\hline Cluster & OVI & Spark & $\begin{array}{c}\text { Iridescent } \\
\text { Ink }\end{array}$ & $\begin{array}{c}\text { W/ } \\
\text { Thread } \\
\text { (up to 2 } \\
\text { mm) }\end{array}$ & $\begin{array}{c}\text { W/ } \\
\text { Thread } \\
\text { (wider2 } \\
\text { mm) }\end{array}$ & $\begin{array}{c}\text { Holo } \\
\text { Thread }\end{array}$ & $\begin{array}{c}\text { Color } \\
\text { changing } \\
\text { Thread }\end{array}$ & Motion & $\begin{array}{c}\text { Dimetallized } \\
\text { Thread }\end{array}$ & $\begin{array}{c}\text { Holostripe } \\
1\end{array}$ \\
\hline 1 & 0.65 & 0.67 & 1.46 & 0.79 & 1.94 & 0.33 & 0.55 & 0.49 & 2.37 & 0.70 \\
\hline 2 & 1.72 & 2.16 & 3.93 & 2.93 & 6.47 & 1.34 & 4.14 & 0.59 & 9.43 & 2.16 \\
\hline
\end{tabular}

N ot e: OVI - optical variable link.

This method enables to trace the cluster formation based on the closest choice of security features starting from small groups and ending up with two large clusters (Table).

As a result, we obtained clusters, whose main difference lay in the number of features used. Clustering allowed us to systematize countries by their approach to the choice of particular security features (Appendix, Table 3).

In order to identify the source of innovations in the banknote production industry, we analysed patent activity by region. The analysis was carried out in the single global patent and copyright database maintained by the European Patent Office. To determine patent activity in the security printing industry in comparison with other existing printing methods and materials, we used subclass B41M as a search criterion (printing, duplicating, marking or copying processes; colour printing) to which group B41M 3/14 (security printing) belongs, according to international patent classification.

Thus, this methodological approach allows us to: (1) identify the main innovations in the industry; (2) to form a temporal and geographical model for the diffusion of each innovation; (3) identify groups of countries where innovations are introduced first and are later diffused globally; (4) group countries by approaches used in selecting innovative solutions; (5) compare information on countries that are the first to adopt innovations with countries where the innovation was created. As a result, we should identify lead markets for the banknote production market and confirm their temporal stability.

\section{RESULTS}

The number of banknote users in the world is limited and constant. The global market is very stable in terms of the number of customers, and despite the fact that from time to time states start issuing their own banknotes, whereas they previously used currencies of other countries, or several countries form currency unions, these events do not have a significant impact on the market. As a rule, one consumer of banknotes corresponds to one country.

In total, around 400 bln banknotes are in circulation throughout the world. Furthermore, despite the development of electronic payment systems, the number of banknotes in circulation continues to grow by about $5 \%$ per year. In order to replace worn-out banknotes in circulation, and to ensure monetary circulation in national economies, about 170 bln new banknotes are issued annually in the world. Overall, the global turnover of the banknote production market is estimated at about $\$ 10$ bln.

The banknote production industry has a number of features that distinguishes it among other industries, including among other types of printing production. The industry has obvious special characteristics in terms of both buyers and manufacturers, as well as in terms of suppliers of materials and equipment. The value created in this 
industry that is protection against unauthorized copying and imitation (counterfeiting) is rather unique.

In total, there are about 60 banknote manufacturers in the world today (the exact figure may vary from year to year, depending on whether a particular factory manufactured banknotes in a given year). Enterprises that manufacture banknotes are most often highly specialized. Banknote production requires special expensive equipment, which has limited application in the manufacture of other printing products. Such enterprises are subject to high security requirements, which restrict manufacture of other products. In addition, a product run from several tens of millions to several billions per year is quite sufficient to fill the production program [Trachuk, Kornilov, 2013b].

Geographically, most of the banknote producers are located in Europe (25 companies), 18 companies are located in Asia, 11 in America, 7 in Africa, and 1 in Australia. At the same time, the largest number of circulating banknotes can be found in Asian countries.

Banknote producers are mostly stateowned and are accountable to central banks or, more rarely, to ministries of finance. There are also six non-state companies, which are almost totally oriented towards obtaining orders for banknote production in the commercial market. All these companies are located in Europe and the USA. The commercial banknote market is estimated at about $\$ 1.5 \mathrm{bln}$, which is about 26 bln banknotes per year.

There are also 25 substrate production companies, most of which are in Europe. They focus mostly on producing paper for banknotes. Only 14 companies in the world manufacture paper and print banknotes at the same time, thus controlling the entire banknote production cycle.

On average, the number of new banknotes issued annually remains stable. The study showed that between 1996 and 2017, more than 3100 unique banknotes were issued, i.e. banknotes that were newly designed or redesigned from the previous series. The number of banknotes of different denominations issued globally remains about the same: banknotes of low denomination 847 variants, high denomination -844 variants, medium denomination - 1400 variants. Taking into account that, on the average, banknotes of seven denominations are issued in a country, the number of variants of medium-denomination banknotes is dominant.

Annually, about 125 new or updated banknotes are put in circulation. About 50 countries annually update one or more banknotes. The spikes in introduction of new banknotes in some years (for example, 2000, 2006, 2012) are not manifestations of a cyclical pattern, but only reflect the situation when, due to internal factors, several countries put new banknotes in circulation in the same year.

Security features on banknotes fit into classical models of product life cycles and the diffusion of innovations [Trachuk, Kornilov, 2013b]. As an example, Fig. 2 shows histograms for the diffusion of the two most used features in modern banknotes - OVI and Spark. Both features use special inks that change colour when the banknote is titled. Spark is an improved OVI. Both inks are produced by the Swiss company SICPA. The vertical scale indicates the number of banknotes on which this feature is used. The dissemination of OVI and Spark features demonstrates the perfect mechanism for promoting innovation in the industry. Moreover, the use of this feature clearly fits into the time frame of our study.

The diffusion of this feature represents a bell-shaped curve that is characteristic of the product's life cycle. After its first appearance in 1987, the feature was most widely diffused by 2008 , when it was used on 228 banknotes. In the same year (2008), a Spark element appeared and started actively penetrating the market, gradually replacing OVI. Other features demonstrate similar life cycle patterns. Finally, it turned out that that OVI is still widely used for the lower denomination banknotes but for the newly issued higher denomination banknote the

PЖM 18 (4): 497-524 (2020) 


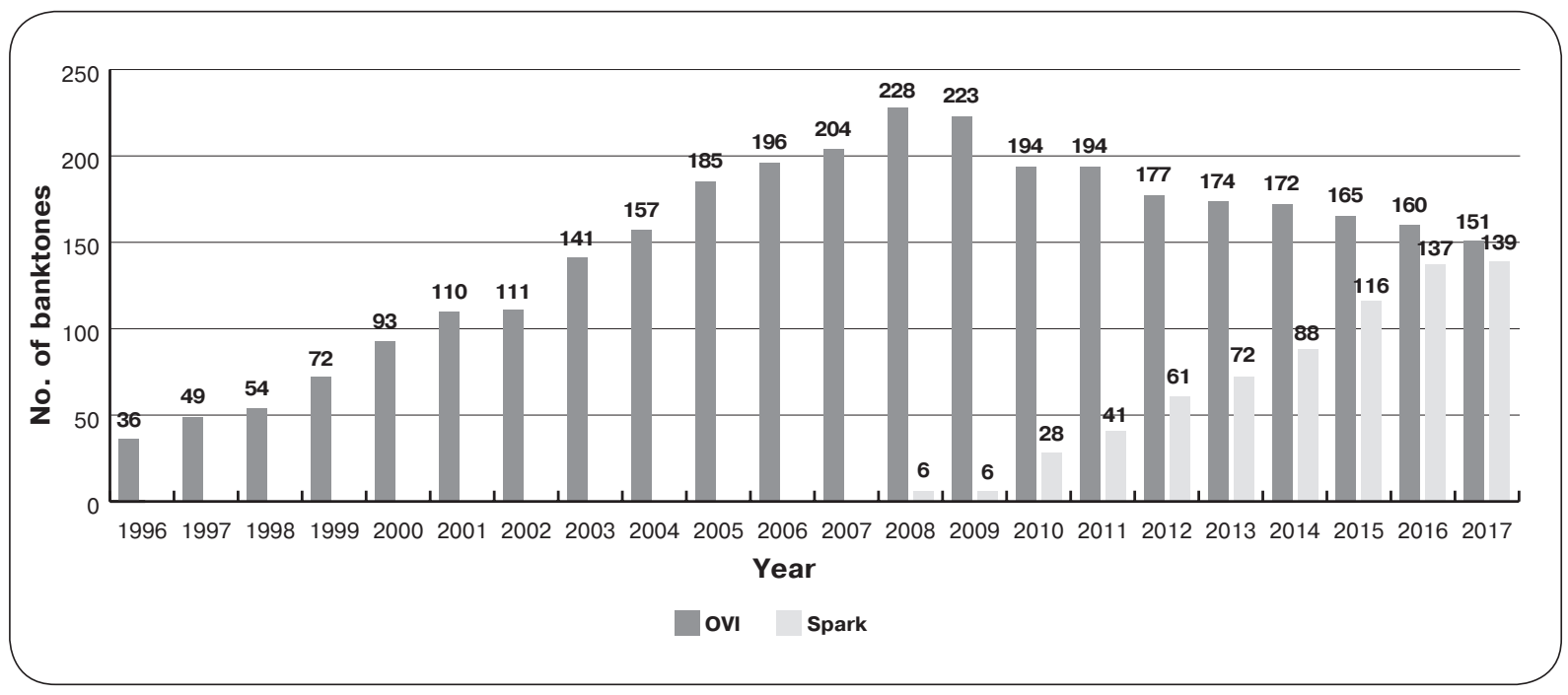

Fig. 2. Global adoption of OVI and Spark security features by 1996-2017

central banks prefer to use more secure and expansive Spark. We can say that Spark has a potential for further increasing its market share reaching at least the figures of previous generation OVI feature.

As a result, it was possible to identify the countries that were always among the first to introduce new security features on their banknotes during the study period. They fell either into the group of countries that were the first to use a certain security feature on their banknotes or into the group of early adopters. These countries include Singapore, Thailand, Scotland, the UAE, Poland, Lebanon, Bangladesh, Chile, Egypt, Latvia, Morocco, and Oman. Countries that come close include Kazakhstan, Malaysia, Russia, and Switzerland (Appendix, Table 2).

Although the countries on the list are very different, the common features inherent to all of them draw attention. Most of these countries regularly update their banknote series, each time introducing new security features. The recommended update cycle is every 5-7 years, but this cycle is shorter in these countries as a whole. Out of the twelve countries that were the first to introduce security features, six of them Thailand, Poland, Bangladesh, Chile, Egypt, and Morocco - have their own production facilities. These countries use modern equipment in their manufacturing process, and conduct independent research in banknote production technology. Thus, they are customers that select security features according to their own analysis of information and practical results. Nevertheless, it should be noted that none of these countries produce banknote printing equipment and that they do not develop their materials and are completely dependent on imported technologies.

The other six countries - Singapore, Scotland, the United Arab Emirates, Lebanon, Latvia, and Oman - do not have their own banknote printing facilities, but they all regularly order new batches of banknotes (every few years). However, the security features are usually updated whenever such orders are placed. These countries have a shorter banknote replacement cycle and can consider using new technologies before others.

Clustering countries by preferences for security features allows us to divide them into two large groups, the main characteristic of which is the number of security features used in banknotes. The countries in the first cluster generally use fewer security features, while the countries in the second cluster use more security features 
in their banknotes. It is worth noting separately the group of countries using polymer banknotes. Although they stand out prominently among the other groups, countries using polymer banknotes generally fall into the first cluster. The clusters do not differ in any way in all other respects, and it is impossible to determine whether there is strong preference to specific security features. On the contrary, security features that are most in demand have high indicators in both clusters (Appendix, Table 2).

Analysis of patent and industry information allowed us to highlight innovation sources in the industry. Secure printing is one of the most patentable fields among all printing methods and materials, lagging behind only digital printing methods. In subgroup B41M 3/14 (secure printing) there are 16 155 patents and copyright certificates issued over the past 5 years, representing $6.38 \%$ of the total patents in the B41M subclass. Secure printing constitutes one of the fastest growing fields of patent activity: over the past 5 years, the number of issued patents has increased by nearly 1.6 times (3 881 patents and 9 th position in the ranking in 2010 compared to 6147 patents and 7th position in 2015).

The leading companies in patent activity in the industry are companies from Germany, Switzerland, the United Kingdom, Japan, and the USA. Corporate leaders include Giesecke \& Devrient (Germany) - 6.05\%, SICPA (Switzerland) - 5.21, Bundesdruckerei (Germany) - 2.04, De La Rue (Great Britain) - 1.98, Dainippon Printing (Japan) 1.92 , and Kurz (Germany) $-1.98 \%$.

Basing our analysis of the top 50 patenting companies in the secure printing industry, we concluded that innovation sources of banknote production are countries such as Germany, Switzerland, the USA, Great Britain, and Japan. All the non-governmental companies producing banknotes are located in these countries (and also in France).

All of the above countries are not included in the risk area linked to counterfeiting. Analysis shows a low counterfeiting level in these countries. In this regard, the development of protection systems in these countries is not related to the counterfeiting threat, or the protection and prevention level is such that counterfeit banknotes do not appear in large quantities.

The analysis of industry information of security features in 22 groups in the study database showed that authorship belongs to companies from Switzerland (3), Germany (4), Japan (1), Great Britain (3), USA (1), and Russia (1). As to the other innovations, it is rather difficult to identify where they were developed first, since they were designed at the same time by different companies. However, these companies were also from the USA, the UK, Switzerland and Germany. All the countries where these companies are based fall into the list of leaders in patent activity in the field of secure printing.

We found a discrepancy between the list of countries that are the first to implement innovations and the list of countries where innovative solutions have been developed. Switzerland is the only country that is included in both lists (it somewhat fell short of the leading countries in the list of first adopters). We note that the lack of interconnection between these lists is steady through time. Countries developing security features are never the first to introduce their developments in their own banknotes. On the contrary, in cases where a development was first introduced in their own banknotes (for example, Canada, the Netherlands, Russia and some other countries), it was not diffused globally. It can be concluded that in the field of banknote production, some countries look to other countries when choosing security features for their banknotes.

Dividing countries by common security features on banknotes has shown that countries that develop security features (Japan, the USA, Switzerland, the United Kingdom, and euro-zone countries) are much alike in choosing the way they protect their banknotes. On the one hand, this suggests a high level of technological cooperation between companies from these countries, and on the

PЖM 18 (4): 497-524 (2020) 
other hand, this is due to the fact that they are guided by tested and proven security solutions that have already been introduced in other markets.

We believe that the pattern for the diffusion of innovations in banknote production is as follows: the source of an innovative product or solution is one of the countries in Europe (Switzerland, Germany, or the UK) or the United States. The developer of a feature is often a private company working in this sector. Subsequently, the feature is introduced on banknotes of the countries for which the developer or partner company manufactures banknotes. The second group of banknotes on which new features are introduced is formed by banknotes of countries that have their own qualified production facilities.

The list of countries that are the first to use new security features does not include countries with a high level of counterfeiting. This is apparently due to two factors. First, manufacturers take a more responsible approach to selecting specific types of security features. Secondly, these countries have a more developed counterfeiting prevention system, which explains the presence of qualified buyers in these countries.

Features used on banknotes of countries with a high level of counterfeiting fall into the group of those that do not gain widespread diffusion. In turn, countries where counterfeiting is rising are guided by the examples of leaders, and adopt the best features used on banknotes circulating in lead markets.

The most important factor for the diffusion of innovations in the banknote industry is technology adoption by lead countries. As the study shows, the features that appeared immediately on banknotes of the developer countries were not guaranteed global success. On the contrary, there is a chance that they will not be diffused, which can be explained by the developer's reluctance to transfer technology or materials to other manufacturers. In some cases, such reluctance can be determined by the first customer's position.

\section{IMPLICATIONS}

We examined the peculiarities related to the diffusion of innovations in markets with monopsony buyers and an oligopolistic supply. Such markets include, in particular, products and solutions designed to address national security objectives. We also identified lead markets, where adoption of innovations precedes their diffusion in other markets. The study was based on data on the global banknote market.

The study showed that when choosing solutions in fields related to national security, states seek to use tested solutions that have proven themselves in other geographical markets. However, there are countries that act as leaders for the industry, that is, innovations introduced in these markets subsequently become an industry standard and are globally diffused. Using the banknote market as an example, we determined that such markets are not found in countries where innovative solutions have been developed. Two groups of national markets act as leaders in the banknote industry. First, countries that have their own modern production and can carry out a competent expert study on the proposed solutions. Second, countries that order development and production from external companies that are industry leaders and developers of innovative solutions.

Thus, lead markets are not those where the product (solution) was developed, but those where the solution was adopted and successfully proved itself. There are at least twelve countries in the banknote market, on whose banknotes most of the new security features that were subsequently diffused globally found their first application. For companies operating in such specific markets as markets for national security solutions this means that the effective implementation of their developments in countries classified into the leader group is the key to successful widespread diffusion of their solutions.

Leadership in developing and implementing solutions in own national market does 
not guarantee global diffusion. Attempts to implement an innovative solution in non-lead markets lead to the solution not gaining widespread diffusion. In addition, a market unstable in terms of national security threat does not inspire confidence in the solution proposed in it, even if the solution itself is not compromised. When there is real danger to national security, this is not the best time to test new solutions.

Our study showed that not only developed markets, but also emerging markets can become lead markets in products for the state. As national security issues addressed by different countries tend to be the same, developers should not be focused solely on developed countries to implement their innovative solutions. Provided they have a stable internal security situation, developing or catching-up countries are well suited for innovation implementation.

With regard to countries seeking national security solutions, the results of our study indicate that conducting own development is not the most effective approach. In order to find an effective national security solution through inter-industry communication mechanisms, it would be better to identify development leaders and markets where solutions are applied first. It is most effective to use solutions launched on the market a few years before. Most developed countries follow this path.

We are convinced that an approach to public procurement market analysis from the standpoint of the lead market concept creates a new understanding of these markets. Topics for further studies can be the following.

1. Studies to confirm the possibility of identifying lead markets in other public procurement fields, in particular, the arms market or the pharmaceutical market. Conclusions of such studies may show that, when making a decision, states can be guided not so much by actual needs, but by innovations adopted in lead markets.

2. It is obvious that the characteristics of a lead market can change over time.
Consequently, the question arises as to the extent to which the lead market attribute remains stable over time. Under what conditions and when can a change in status occur?

3. Does a lead country get real benefits from its status, or, on the contrary, it incurs costs associated with the testing of new technologies and pays a premium for the possibility of being the first to implement an innovation?

\section{CONCLUSION}

Analysis of the banknote market from the point of view of the lead market concept contributes to the development of innovation adoption theory. Firstly, it demonstrates that the same principles for diffusion of innovations operate in the market for products for the state, which is characterized by a monopsonic demand, as in markets for other products. Secondly, orientation towards lead markets is one of the most important factors in choosing an innovative solution for government procurement of products (solutions) for national security needs.

When choosing a strategy to market new products, companies operating in the banknote industry should primarily focus on countries that have their own production. In case such new products become successful in these countries, they are more likely to be diffused more widely in the industry on a global scale. On the other hand, a new security feature initially introduced in the market where there is a high threat level (in the case of banknotes, the counterfeiting threat), does expose it to the risk that it will not gain diffusion. A similar situation arises when innovations are introduced on the developer's home market.

The methodological approach used to identify lead markets has several restrictions. In particular, the banknote market is quite distinct and data on banknote issuance are readily available. As regards other markets,

PЖM 18 (4): 497-524 (2020) 
where the state or its agents are customers, it may turn out to be more difficult to identify the diffusion of innovations. In this regard, other methods will be needed to identify lead markets.

We believe that the approach involving identification of lead markets is applicable to other markets that have state buyers. On the one hand, it will lead to a better understanding of decision-making logic in adopting innovations, and on the other, it can guide suppliers as to the most efficient markets in terms of subsequent diffusion of innovative products.

Appendix

Table 1

Groups and individual security features and technologies used in banknote production chosen for analysis

\begin{tabular}{|c|c|}
\hline Group of security features and security technologies & Security feature or technology \\
\hline Colour shift & $\begin{array}{l}\text { Optical variable inks (OVI) } \\
\text { Optical variable magnetic inks (Spark) } \\
\text { Iridescent inks } \\
\text { Other (DID, Lead, etc.)* }\end{array}$ \\
\hline Holograms & $\begin{array}{l}\text { Holographic patch } \\
\text { Holographic stripe }\end{array}$ \\
\hline Substrate & $\begin{array}{l}\text { Paper* } \\
\text { Durable paper } \\
\text { Polymer substrate } \\
\text { Post-print varnishing* }\end{array}$ \\
\hline Security threads (by width) & $\begin{array}{l}\text { Narrow widow thread (up to } 2 \mathrm{~mm} \text { ) } \\
\text { Wide window thread (over } 2 \mathrm{~mm} \text { ) } \\
\text { Fully embedded thread }\end{array}$ \\
\hline Security thread (by visual appearance) & $\begin{array}{l}\text { Holographic thread } \\
\text { Colour shifting thread } \\
\text { Thread with moving image (Motion) } \\
\text { Rolling Star thread } \\
\text { Security thread with demetallization } \\
\text { Other types* }\end{array}$ \\
\hline Transparent window in substrate & $\begin{array}{l}\text { Made by die-cutting } \\
\text { Security thread with transparent window } \\
\text { Transparent widow in polymer - excluded }\end{array}$ \\
\hline Printed features & $\begin{array}{l}\text { Combination of offset and intaglio printing* } \\
\text { Blind embossing } \\
\text { Omron rings } \\
\text { Foil embossing } \\
\text { Metallic inks } \\
\text { Up-converting inks* } \\
\text { Infra-red inks } \\
\text { POLE* } \\
\text { Thermochromic ink* }\end{array}$ \\
\hline
\end{tabular}

N ot e: * excluded. 
Countries on which banknotes new security features are introduced in periods preceding to mass adoption

\begin{tabular}{|c|c|c|c|c|c|}
\hline Country & $\begin{array}{c}\text { Total new } \\
\text { features } \\
\text { implemented }\end{array}$ & $\begin{array}{l}\text { Implemented } \\
\text { amongst the } \\
\text { first }\end{array}$ & $\begin{array}{l}\text { Implemented } \\
\text { after first } 10\end{array}$ & $\begin{array}{l}\text { Implemented } \\
\text { before the mass } \\
\text { adoption }\end{array}$ & Average figure \\
\hline Singapore & 9 & 5 & 3 & 7 & 5.0 \\
\hline Thailand & 8 & 5 & 4 & 8 & 5.7 \\
\hline Scotland & 8 & 5 & 4 & 3 & 4.0 \\
\hline UAE & 7 & 5 & 4 & 3 & 4.0 \\
\hline Poland & 7 & 4 & 4 & 3 & 3.7 \\
\hline Lebanon & 6 & 5 & 2 & 5 & 4.0 \\
\hline Bangladesh & 6 & 3 & 5 & 4 & 4.0 \\
\hline Chili & 6 & 3 & 6 & 2 & 3.7 \\
\hline Egypt & 6 & 5 & 2 & 3 & 3.3 \\
\hline Latvia & 6 & 4 & 3 & 3 & 3.3 \\
\hline Morocco & 6 & 4 & 2 & 3 & 3.0 \\
\hline Oman & 6 & 3 & 2 & 4 & 3.0 \\
\hline Malaysia & 5 & 4 & 5 & 5 & 4.7 \\
\hline Russia & 5 & 3 & 3 & 3 & 3.0 \\
\hline Switzerland & 5 & 2 & 3 & 4 & 3.0 \\
\hline Jamaica & 5 & 4 & 1 & 3 & 2.7 \\
\hline Bulgaria & 5 & 4 & 2 & 2 & 2.7 \\
\hline Botswana & 5 & 3 & 3 & 2 & 2.7 \\
\hline Hong Kong & 5 & 3 & 3 & 2 & 2.7 \\
\hline Zambia & 5 & 4 & 2 & 1 & 2.3 \\
\hline China & 5 & 3 & 3 & 1 & 2.3 \\
\hline Estonia & 5 & 3 & 2 & 2 & 2.3 \\
\hline Bermuda & 5 & 2 & 3 & 2 & 2.3 \\
\hline Nepal & 5 & 1 & 3 & 2 & 2.0 \\
\hline $\begin{array}{l}\text { Kyrgyz } \\
\text { Republic }\end{array}$ & 5 & 1 & 1 & 4 & 2.0 \\
\hline $\begin{array}{l}\text { United } \\
\text { Kingdom }\end{array}$ & 4 & 4 & 3 & 3 & 3.3 \\
\hline Djibouti & 4 & 3 & 3 & 4 & 3.3 \\
\hline Kazakhstan & 4 & 3 & 3 & 3 & 3.0 \\
\hline Finland & 4 & 2 & 3 & 4 & 3.0 \\
\hline Bahamas & 4 & 1 & 4 & 3 & 2.7 \\
\hline
\end{tabular}


Table 2 (end)

\begin{tabular}{|c|c|c|c|c|c|}
\hline Country & $\begin{array}{c}\text { Total new } \\
\text { features } \\
\text { implemented }\end{array}$ & $\begin{array}{l}\text { Implemented } \\
\text { amongst the } \\
\text { first }\end{array}$ & $\begin{array}{l}\text { Implemented } \\
\text { after first } 10\end{array}$ & $\begin{array}{l}\text { Implemented } \\
\text { before the mass } \\
\text { adoption }\end{array}$ & Average figure \\
\hline Belgium & 4 & 2 & 3 & 2 & 2.3 \\
\hline Germany & 4 & 1 & 3 & 3 & 2.3 \\
\hline Samoa & 4 & 0 & 3 & 4 & 2.3 \\
\hline Belarus & 4 & 3 & 1 & 2 & 2.0 \\
\hline Lesotho & 4 & 2 & 1 & 3 & 2.0 \\
\hline Malawi & 4 & 1 & 2 & 3 & 2.0 \\
\hline Mexico & 4 & 2 & 2 & 1 & 1.7 \\
\hline Sweden & 4 & 2 & 2 & 1 & 1.7 \\
\hline Taiwan & 4 & 2 & 2 & 1 & 1.7 \\
\hline Faroes Island & 4 & 2 & 1 & 2 & 1.7 \\
\hline Armenia & 4 & 2 & 2 & 1 & 1.7 \\
\hline Cabo Verde & 4 & 2 & 2 & 1 & 1.7 \\
\hline New Zealand & 4 & 3 & 1 & 0 & 1.3 \\
\hline
\end{tabular}

Table 3

Clusters of countries by their approach to the choice of banknote security features

\begin{tabular}{|c|c|}
\hline Cluster 1 & Cluster 2 \\
\hline $\begin{array}{l}\text { Afghanistan, Albania, Algeria, Association of three } \\
\text { overseas territories of France, Australia, Azerbaijan, } \\
\text { Belize, Bermuda, Bolivia, Botswana, Brazil, Brunei, } \\
\text { Bulgaria, Butane, Cambodia, Canada, Cape Verde, } \\
\text { Cayman islands, Chile, China, Congo, Costa Rica, } \\
\text { Croatia, Cuba, Czech Republic, Denmark, Estonia, } \\
\text { European Monetary Union, Falkland Islands, Faroe } \\
\text { Islands (Denmark), Fiji, Gambia, Georgia, Ghana, } \\
\text { Gibraltar, Guernsey, Guyana, Haiti, Honduras, } \\
\text { Iceland, Iran, Israel, Japan, Jersey, Laos, Latvia, } \\
\text { Lesotho, Liberia, Macedonia, Madagascar, Malaysia, } \\
\text { Maldives, Mauritania, Mauritius, Mexico, Moldova, } \\
\text { Mongolia, Mozambique, Myanmar, New Zealand, } \\
\text { Nigeria, Northern Ireland, Norway, Pakistan, Papua } \\
\text { New Guinea, Peru, Qatar, Romania, Russia, Samoa, } \\
\text { Saudi Arabia, Sierra Leone, Singapore, Solomon } \\
\text { Islands, South Korea, Sudan, Sweden, Switzerland, } \\
\text { Syria, Taiwan (Republic of China), Tanzania, The } \\
\text { Economic Community of Central Africa, Trinidad } \\
\text { and Tobago, Ukraine, United Kingdom, Uruguay, } \\
\text { USA, Uzbekistan, Vanuatu, Venezuela, Vietnam, } \\
\text { West African Economic and Monetary Union, } \\
\text { Yemen, Zimbabwe }\end{array}$ & $\begin{array}{l}\text { Angola, Argentina, Armenia, Bahamas, Bahrain, } \\
\text { Bangladesh, Barbados, Belarus, Bosnia and } \\
\text { Herzegovina, Burundi, Colombia, Dominican } \\
\text { Republic, East-Caribbean Monetary Union, Egypt, } \\
\text { Eritrea, Guatemala, Guinea, Hong Kong, } \\
\text { Hungary, India, Indonesia, Iraq, Jamaica, } \\
\text { Kazakhstan, Kuwait, Kyrgyzstan, Lebanon, Libya, } \\
\text { Macao, Malawi, Morocco, Namibia, Nepal, } \\
\text { Nicaragua, North Korea, Oman, Paraguay, } \\
\text { Philippines, Poland, Rwanda, Scotland, Serbia, } \\
\text { Seychelles, South Africa, South Sudan, } \\
\text { Sri Lanka, Suriname, Swaziland, Tajikistan, } \\
\text { Thailand, Tonga, Transnistria, Tunisia, Turkey, } \\
\text { Turkmenistan, Uganda, United Arab Emirates, } \\
\text { Zambia }\end{array}$ \\
\hline
\end{tabular}




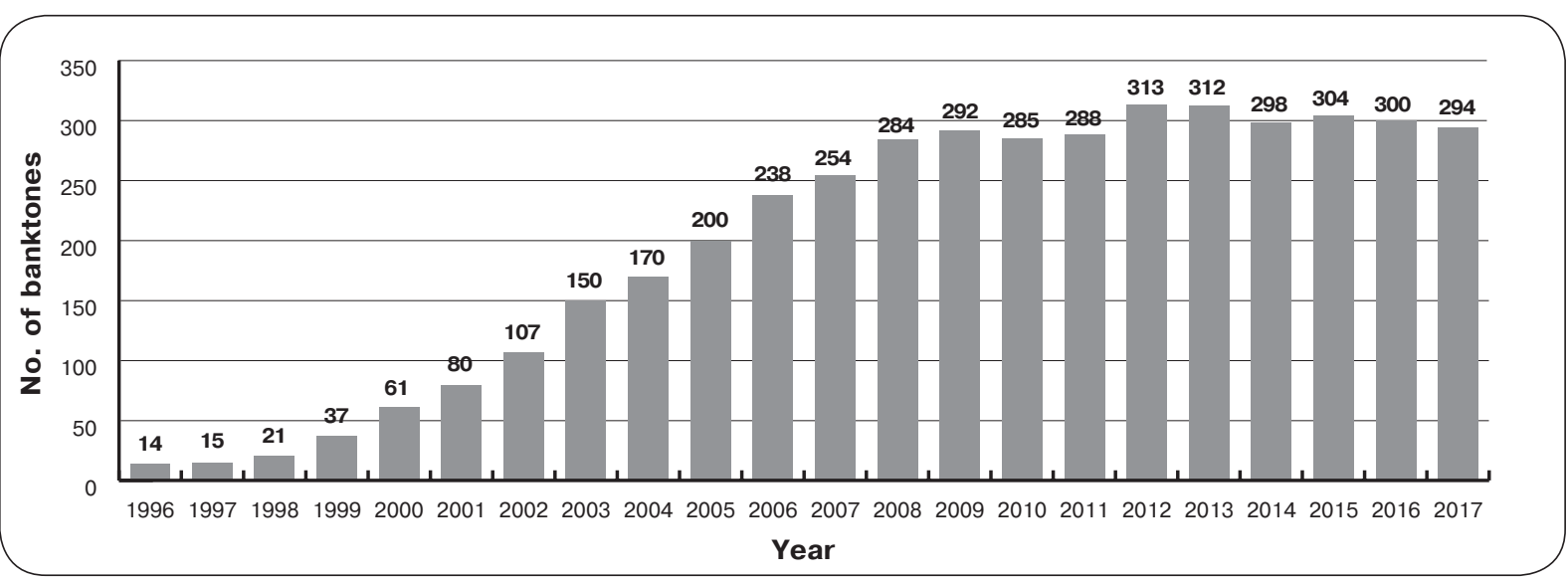

Fig. 1. Banknotes in circulation with Iridescent ink

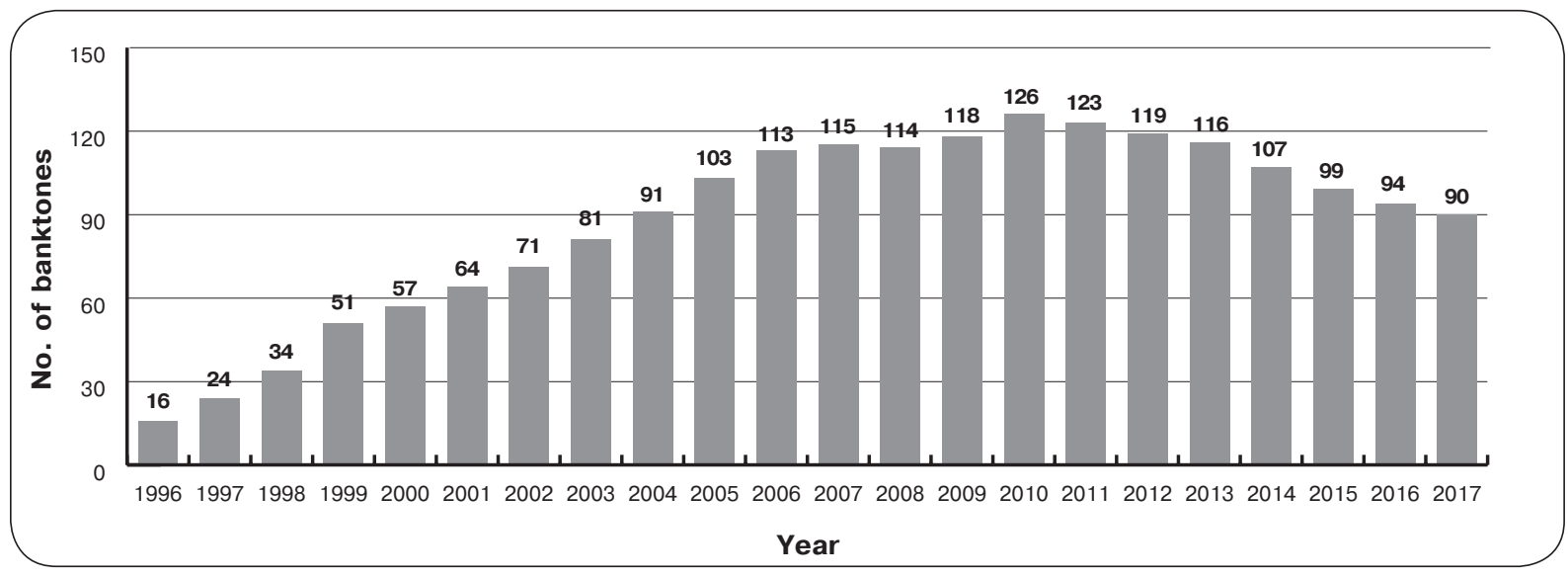

Fig. 2. Banknotes in circulation with holographic patch

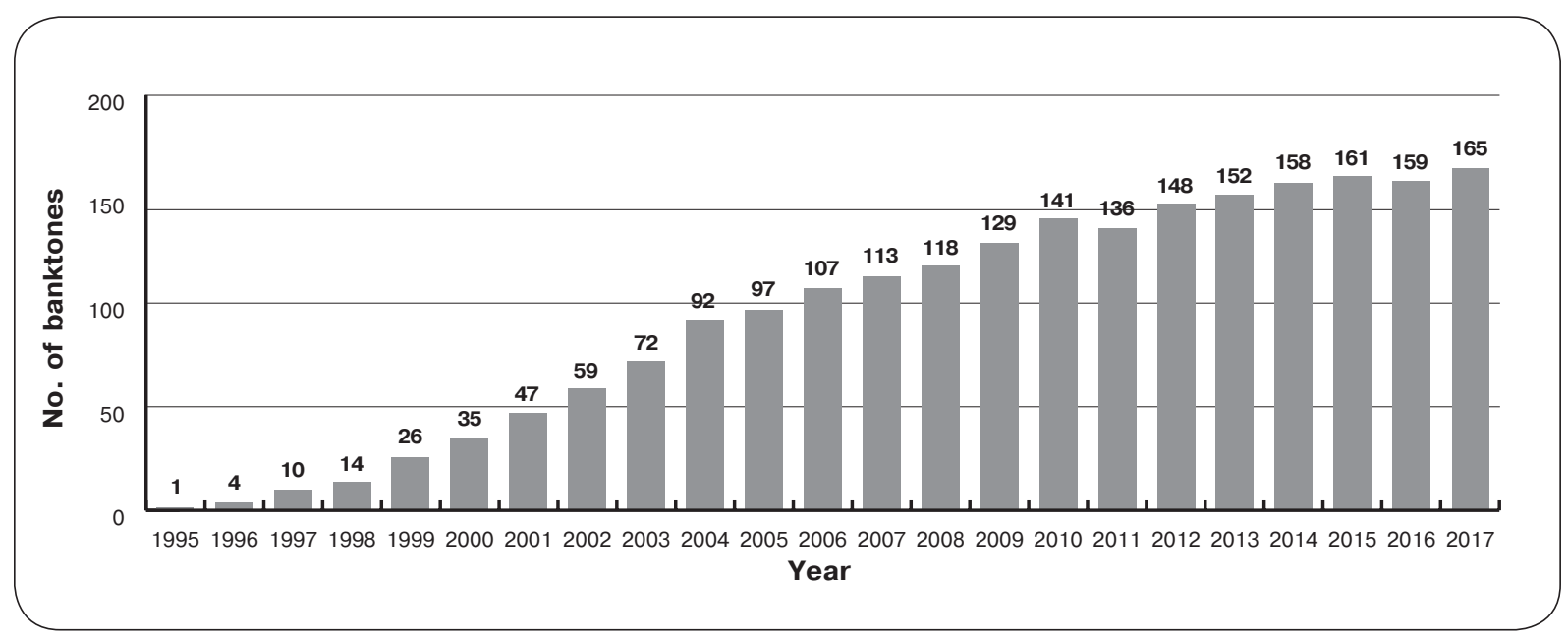

Fig. 3. Banknotes in circulation with holographic strip

РЖM 18 (4): 497-524 (2020) 


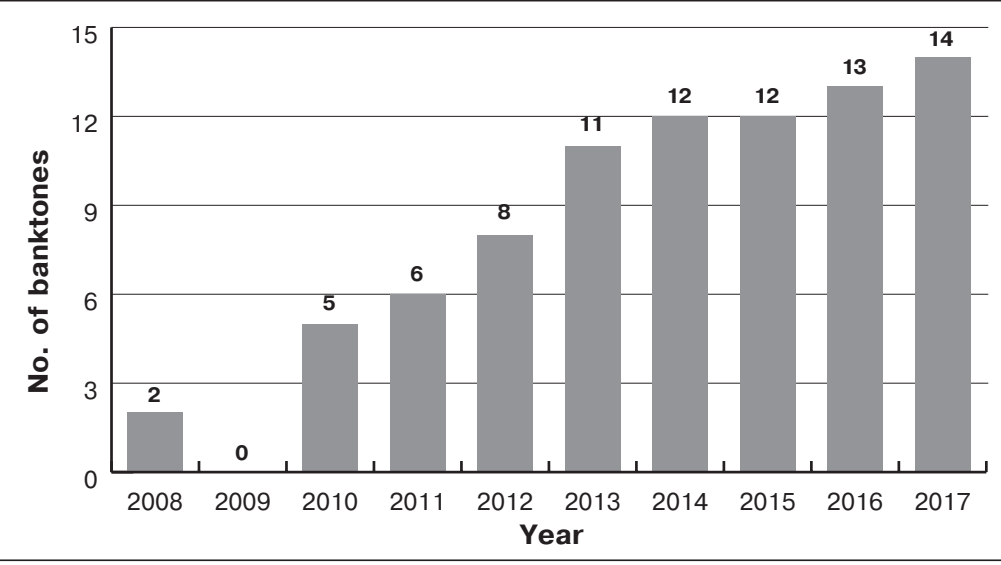

Fig. 4. Banknotes in circulation with durable paper

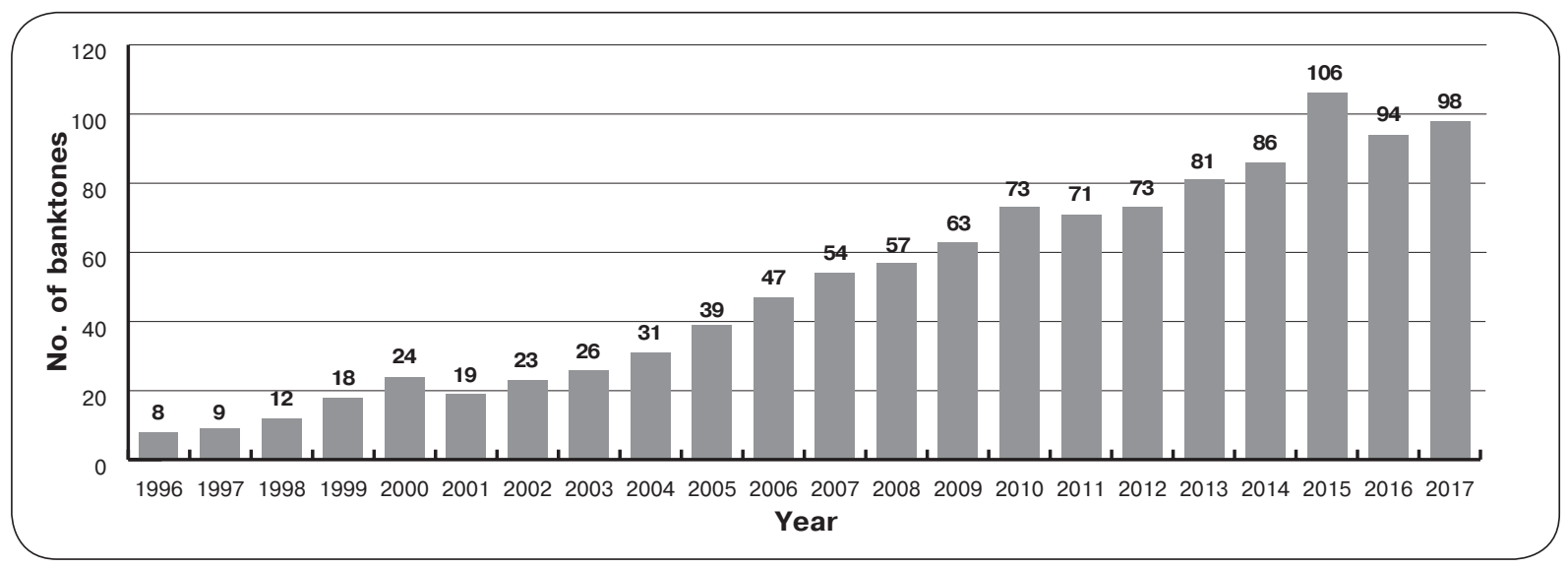

Fig. 5. Banknotes in circulation with polymer substrate

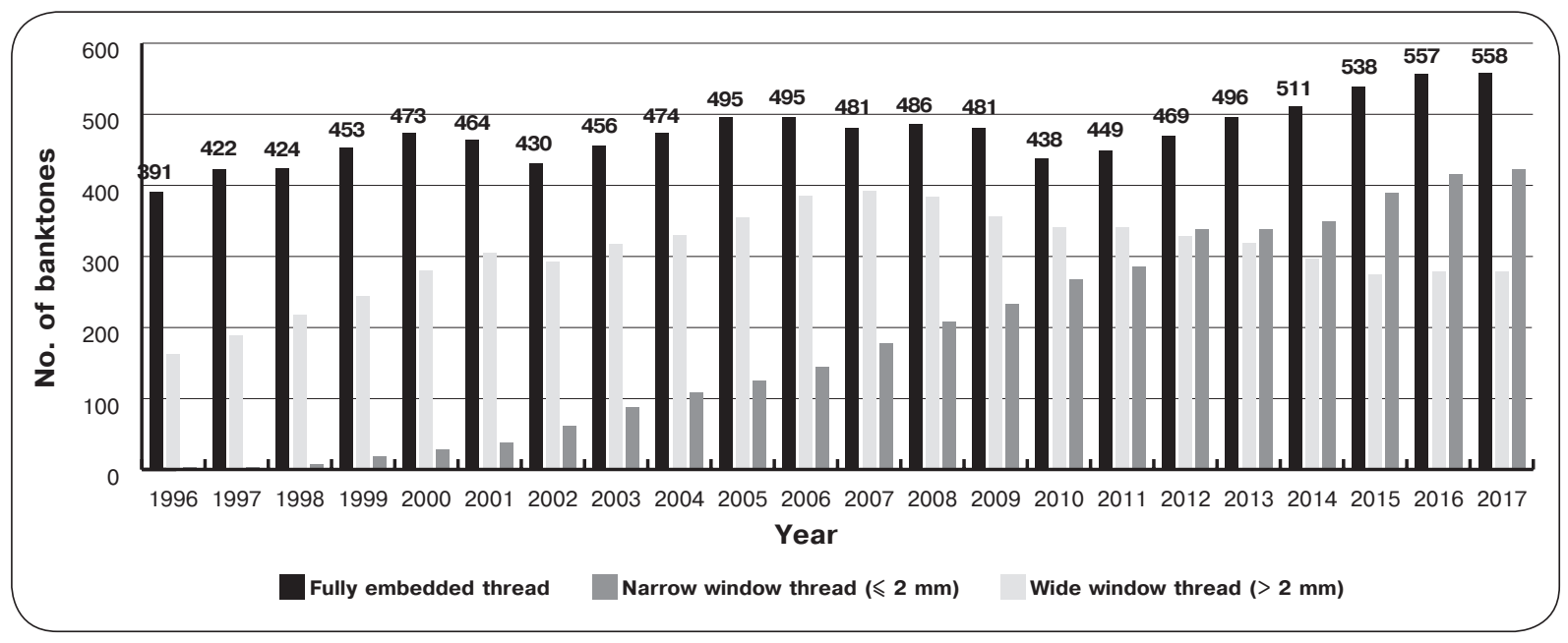

Fig. 6. Banknotes in circulation with security thread 


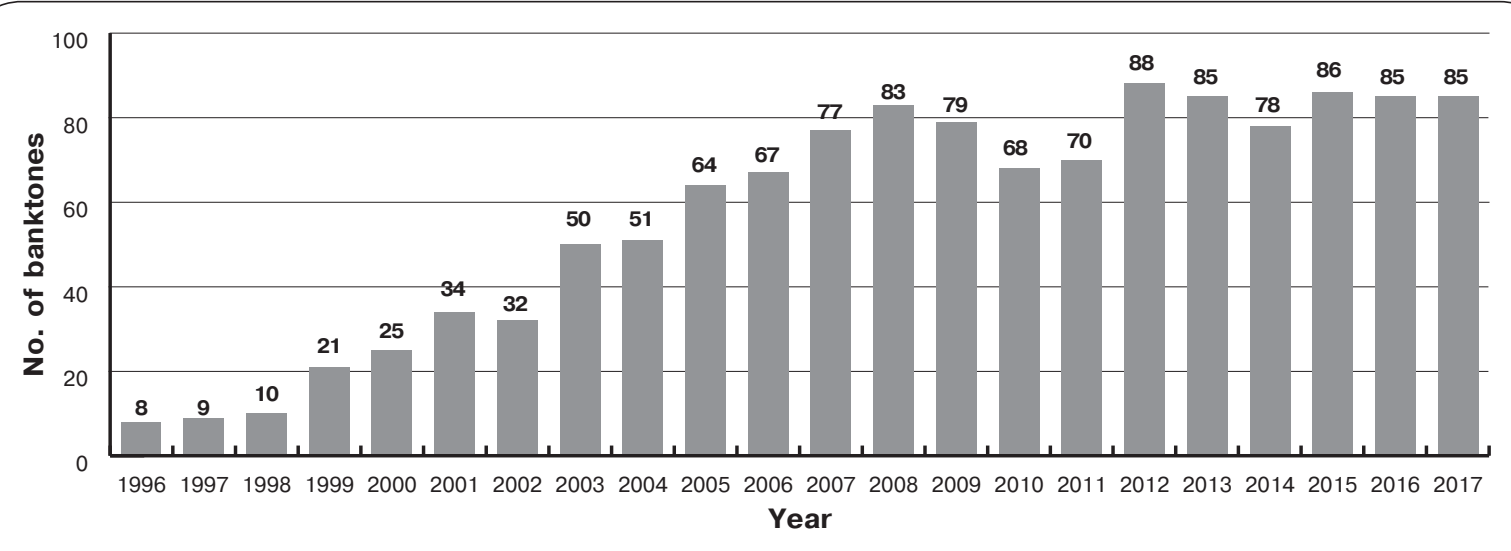

Fig. 7. Banknotes in circulation with holographic thread

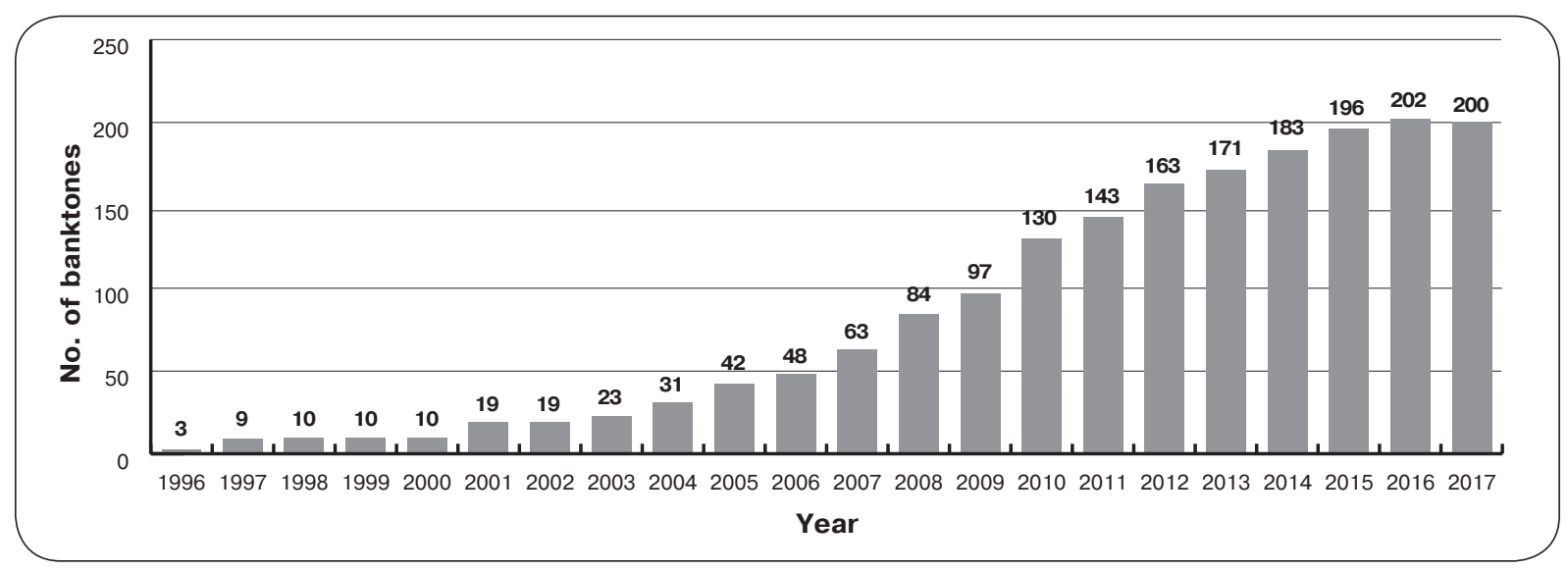

Fig. 8. Banknotes in circulation with colour shifting thread

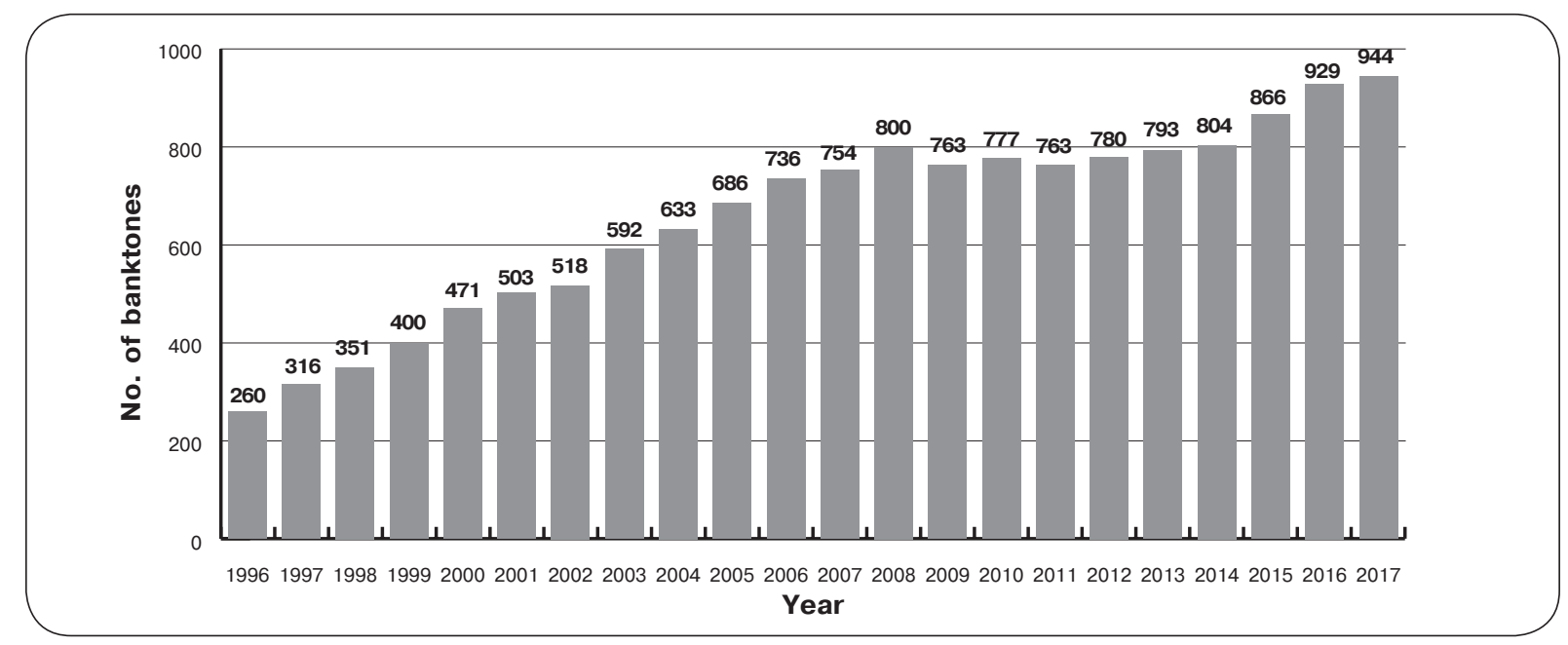

Fig. 9. Banknotes in circulation with colour shifting thread

РЖM 18 (4): 497-524 (2020) 


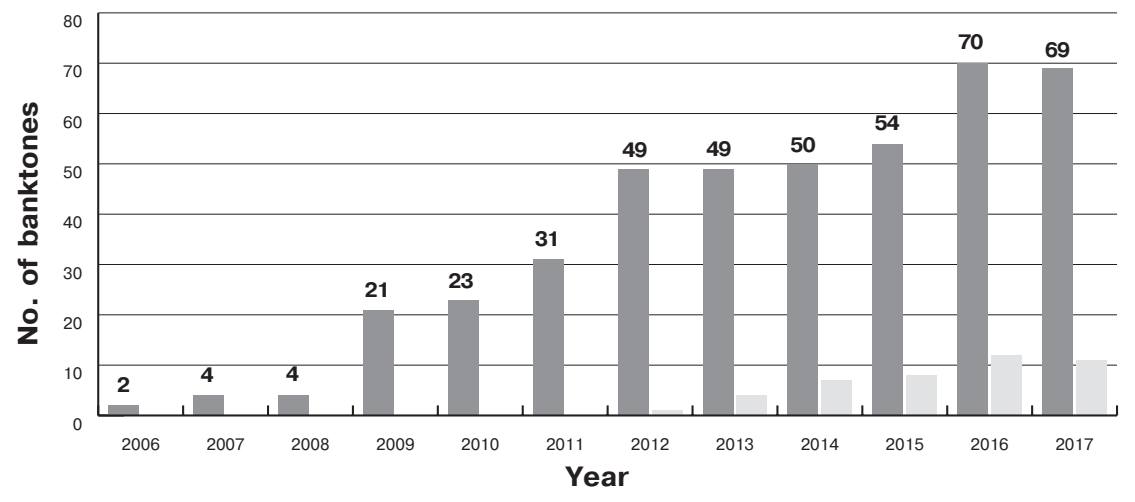

Motion

Rolling Star

Fig. 10. Banknotes in circulation with thread

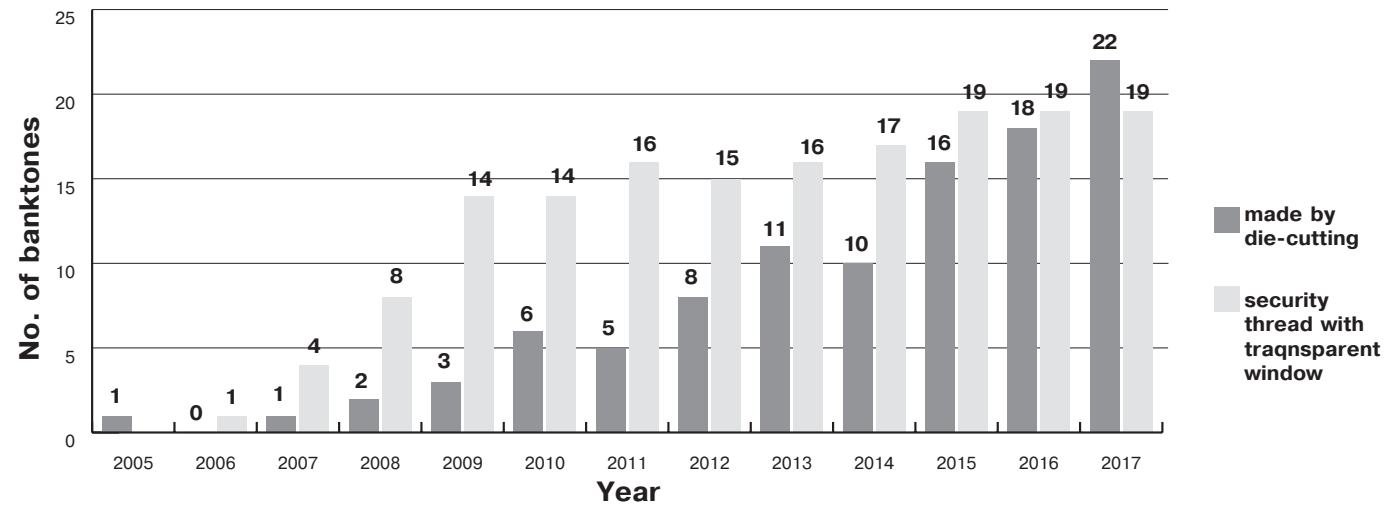

Fig. 11. Banknotes in circulation with security features

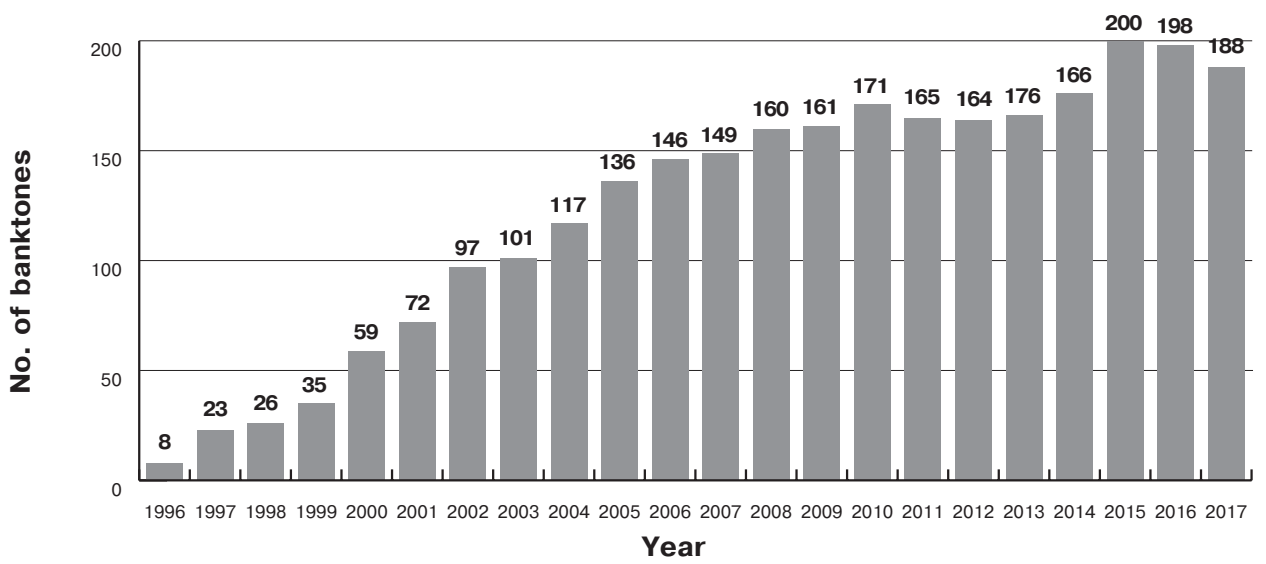

Fig. 12. Banknotes in circulation with blind embossing 


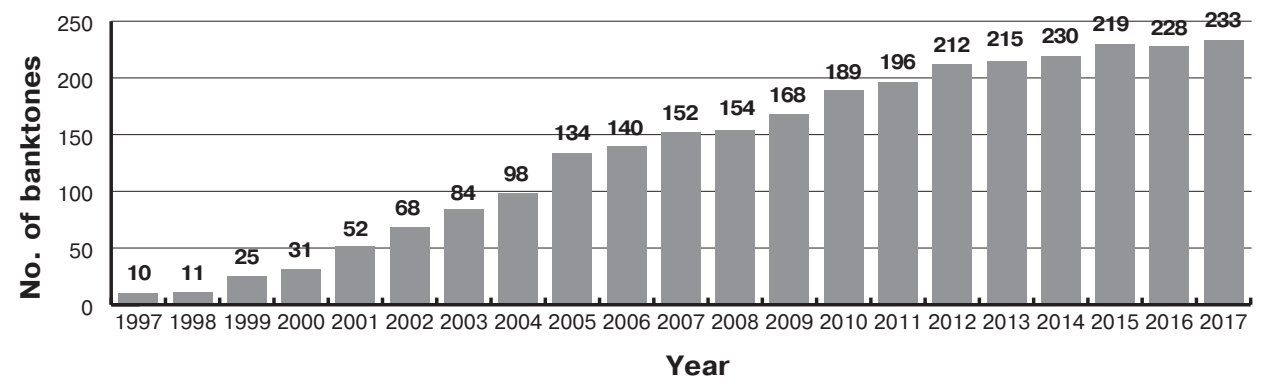

Fig. 13. Banknotes in circulation with omron rings

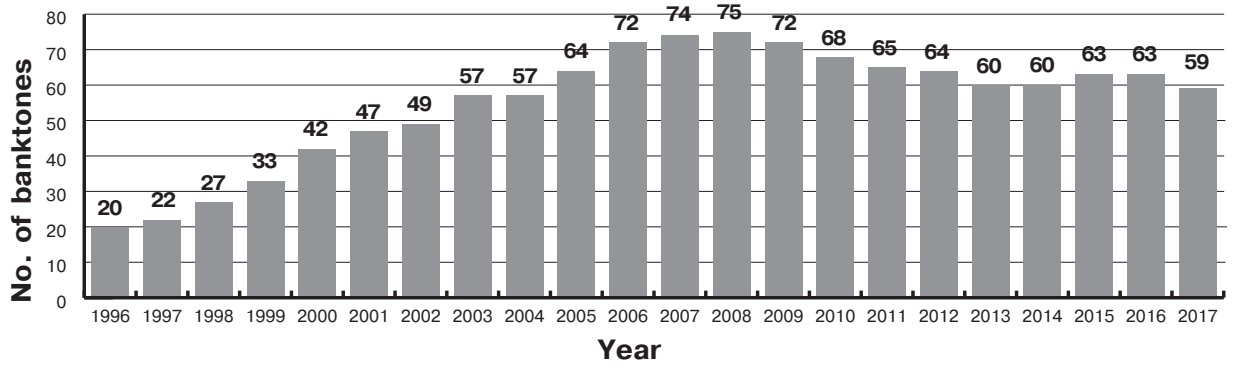

Fig. 14. Banknotes in circulation with foil embossing

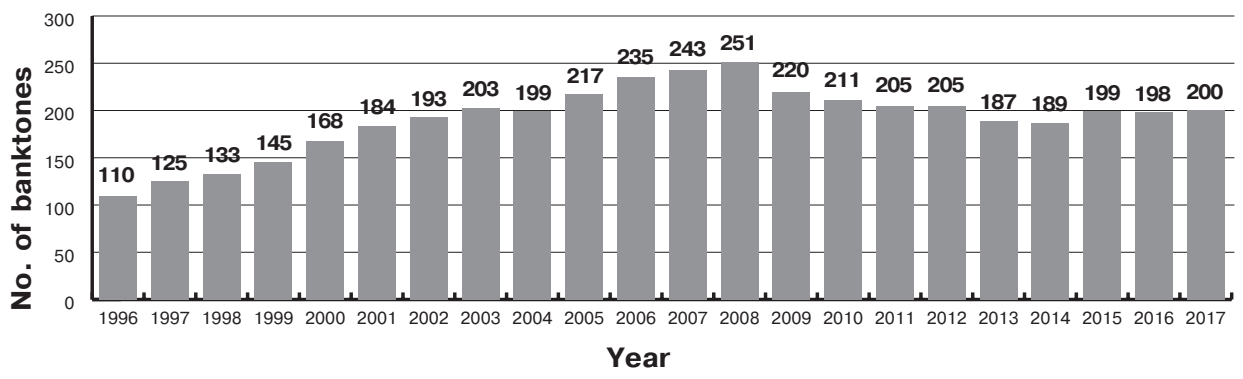

Fig. 15. Banknotes in circulation with metallic ink

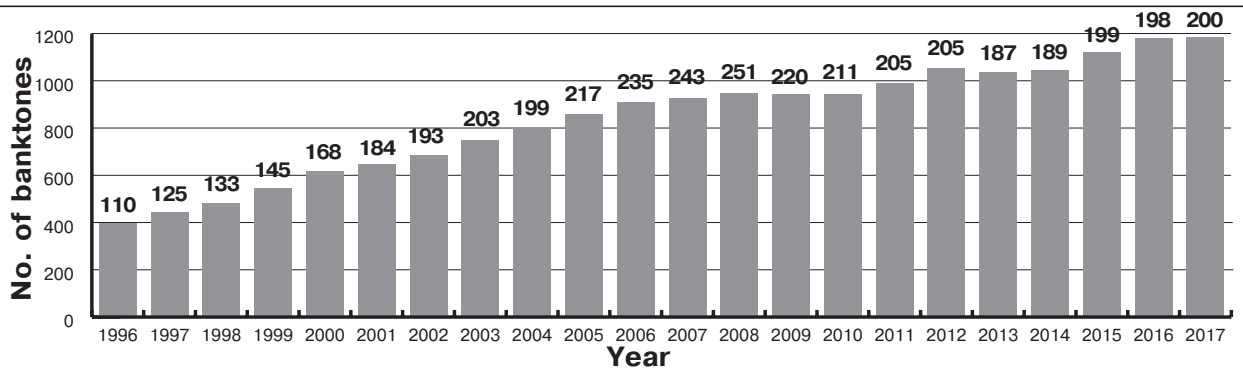

Fig. 16. Banknotes in circulation with Infra-red inks 


\section{REFERENCES}

Barrdear J., Kumhof M. 2016. The macroeconomics of Central Bank issued digital currencies. Staff Working Paper 605. Bank of England. [Electronic resource]. https://www. bankofengland.co.uk/-/media/boe/files/ working-paper/2016/the-macroeconomics-ofcentral-bank-issued-digital-currencies.pdf? la $=$ en\&hash $=341 \mathrm{~B} 602838707 \mathrm{E} 5 \mathrm{D} 6 \mathrm{FC} 26884$ 588C912A721B1DC1 (accessed: 01.06.2020).

Beise M. 2001. Lead Markets: Country-Specific Success Factors of the Global Diffusion of Innovations. Physika-Verlag: Heidelberg.

Beise M. 2004. Lead markets: Country specific drivers of the global diffusion of innovations. Research Policy 33 (6-7): 997-1018.

Beise M. 2006. Die Lead-Markt-Strategie: Das Geheimnis Weltweit Erfolgreicher Innovationen. Springer: Heidelberg. (In German)

Beise M., Gemunden H. G. 2004. Lead markets: A new framework for the international diffusion of innovation. Management International Review 44 (Special Issue 2004/03): 83-102.

Beise M., Rennings K. 2005. "Lead markets and regulations: A framework for analyzing the international diffusion of environmental innovations. Ecological Economics 52 (1): 5-17.

Beise M., Cleff T., Heneric O., Rammer C. 2002. Lead Market Germany. Germany's Position as a Leading Sales Market for Innovation. ZEW Documentation No. 0202. Centre for European Economic Research: Mannheim.

Beise M., Cleff T. 2004. Assessing the lead market potential of countries for innovation projects. Journal of International Management 10 (4): 453-477.

Bender K. 2006. Moneymaker: Secret World of Banknote Printing. Wiley VCH.

Bilgram V., Brem A., Voigt K. 2008. Usercentric innovations in new product development- systematic identification of Lead User harnessing interactive and collaborative online tools. International Journal of Innovation Management 12 (3): 419-458.
Bonnell A. 2010. Covert Tagging. Pira International Ltd: Surrey.

Cleff T., Grimpe C., Rammer C. 2007. The Role of Demand in Innovation - A Lead Market Analysis for High-tech Industries in the EU-25. ZEW Documentation No. 07-02. Centre for European Economic Research: Mannheim.

Cleff T., Grimpe C., Rammer C. 2015. Identifying Lead Markets in the European Automotive Industry: An Indicator-based Approach. Industry and Innovation 22 (6): 496-522.

Deffuant G., Huet S., Amblard F. 2005. An individual-based model of innovation diffusion mixing social value and individual benefit. American Journal of Sociology 110 (4): 1041-1069.

Digital Ruble. 2020. Bank of Russia. [Electronic resource]. https://www.cbr.ru/analytics/ d_ok/dig_ruble/(accessed: 01.02.2021)(In Russian)

European Commission. 2007. 1-44 Explanatory Paper on the European Lead Market Approach: Methodology and Rationale (Annex II to COM (2007) 860 final).

FATF. 2013. Money Laundering and Terrorist Financing Related to Counterfeiting of Currency. [Electronic resource]. https://www. fatf-gafi.org/media/fatf/documents/reports/money-laundering-terrorist-financing-related-to-counterfeit-currency.pdf (accessed: 01.02.2021).

Fliegel F., Kivlin J. 1966. Attributes of innovations as factors in diffusion. American Journal of Sociology 72 (3): 235-248.

Franke N., Von Hippel E., Schreier M. 2006. Finding commercially attractive user innovations: A test of Lead-User theory. Journal of Product Innovation Management 23 (4): 301-315.

Gansler J. S. 2016. Maintaining US leadership in science, technology, and innovation for national security. In: E. Paté-Cornell, W. B. Rouse, C. M. Vest. (eds). Perspectives on Complex Global Challenges: Edu- 
cation, Energy, Healthcare, Security, and Resilience, 155-158. Willey: Hoboken.

Geroski P. A. 1990. Innovation, technological opportunity, and market structure. Oxford Economic Papers 42 (3): 586-602.

Hafeez K., Hooi Keoy K., Hanneman R. 2006. E-business capabilities model validation and comparison between adopter and nonadopter to e-business companies in UK. Journal of Manufacturing Technology Management 17 (6): 806-828.

De Hej H. 2009. Banknote design for the visually impaired. DNB Occasional Studies 7 (2).

De Hej H. 2010. Innovative approaches to the selection of banknote security features. Banknotes of the World (9): 8-15.

Henderson M., Clark K. 1990. Architectural innovation: The reconfiguration of existing product technologies and the failure of established firms. Administrative Science Quarterly 35 (1): 9-30.

Herstatt C., Tiwari R. 2016. Lead Market India: Key Elements and Corporate Perspectives for Frugal Innovations. Springer: Heidelberg.

Iles I. A., Egnoto M. J., Fisher Liu B., Ackerman G., Roberts H., Smith D. 2017. Understanding the adoption process of national security technology: An integration of diffusion of innovations and volitional behavior theories. Risk Analysis 37 (11): 2246-2259.

IBDA banknote database. 2018. International Banknote Designers Association (IBDA). [Electronic resource]. https://www.irsbanknotes.com/ (accessed: 01.06.2020).

Janicke M., Jacob K. 2005. Ecological Modernisation and the Creation of Lead Markets. In: Towards Environmental Innovation Systems, 175-193. Weber M., J. Hemmelskamp (eds). Springer: Heidelberg.

Jog C., Kosmopoulou G. 2014. Experimental evidence on the performance of emission trading schemes in the presence of an active secondary market. Applied Economics 46 (5): 527-538.

Ketterer J. A., Andrade G. 2016. Digital Central Bank Money and the Unbundling of the Banking Function. Discussion Paper
№ IDB-DP-449. Inter-American Development Bank.

Kirkwood J. B. 2016. Buyer power and healthcare prices. Washington Law Review 91 (1): 253-293.

Kumar V., Ganesh J., Echambadi R. 1998. Cross-national diffusion research: What do we know and how certain are we? Journal of Product Innovation Management 15 (3): 255-268.

Lundvall B.-A. (ed.) 1992. National Systems of Innovation: Towards a Theory of Innovation and Interactive Learning. Pinter: London.

Linton J. 2018. Quiet contributors: The role of the Arts, Humanities and Social Sciences in innovation. Foresight and STI Governance 12 (3): 6-12.

Lüthje C., Herstatt C. 2004. The Lead User method: An outline of empirical findings and issues for future research. R\&D Management 35 (5): 553-568.

Mahoney C. W. 2017. Buyer beware: How market structure affects contracting and company performance in the private military industry. Security Studies 26 (1): 30-59.

Morrison P., Roberts J., von Hippel E. 2000. Determinants of user innovation and innovation sharing in a local market. Management Science 46 (12): 1513-1527.

Mowery D. C. 2009. National security and national innovation systems. Journal of Technology Transfer 34 (5): 455-473.

Nijssen E. J., Reinders M. J., Krystallis A., Tacken G. 2019. Developing an internationalization strategy using diffusion modeling: The case of greater amberjack. Fishes 4 (1).

Nelson R. (ed.) 1993. National Innovation Systems. A Comparative Analysis. Oxford University Press: Oxford.

Nelson R. 1995. Co-evolution of industry structure, technology and supporting institutions, and the making of comparative advantage. International Journal of the Economics of Business 2 (2): 171184.

Omwansa T. K., Sullivan N. P. 2012. Money, Real Quick: The story of M-PESA. Guardian Books: London. 
Pizzanelli D. 2011. The Future of Banknote Printing to 2016. Market and Technology Forecast. Pira International Ltd: Surrey.

Quitzow R., Walz R., Köhler J., Rennings R. 2014. The concept of "lead markets" revisited: Contribution to environmental innovation theory. Environmental Innovation and Societal Transitions 10: 4-19.

Rabinovich B. 2007. Cluster analysis of telephone communications detalization. Sistemi i Sredstva Informatiki 17 (1): 52-78. (In Russian)

Rennings K., Smidt W. 2010. A lead market approach towards the emergence and diffusion of coal-fired power plant technology. Economica Politica 2: 303-328.

Rogers E. 2003. Diffusion of Innovations (5th ed.). The Free Press: N.Y.

Rothwell R. 1994. Towards the fifth-generation innovation process. International Marketing Review 11 (1): 7-31.

Straub E. 2009. Understanding technology adoption: Theory and future directions for informal learning. Review of Educational Research 79 (2): 625-649.

Szajnfarber Z., Richards M. G., Weigel A. L. 2011. Challenges to innovation in the Government Space Sector. Defense Acquisition Review Journal 59 (1): 257-276.
Taganov D. 2005. SPSS: Statistic analysis in market surveys. Piter: Saint Petersburg. (In Russian)

Tiwari R., Herstatt C. 2012. Frugal innovation: A global networks' perspective. Swiss Journal of Business Research and Practice 66 (3): 245-274.

Trachuk A., Golembiovsky D. 2012. Perspectives for the expansion of non-cash retail payments. Dengi i Credit (7): 24-32. (In Russian)

Trachuk A., Kornilov G. 2013a. Analysis of factors affecting the spread of non-cash payments in the retail market. Vestnik $\mathrm{Fi}^{-}$ nansovogo Universiteta (4): 6-20. (In Russian)

Trachuk A., Kornilov G. 2013b. Dynamics of innovation introduction into banknote manufacturing. Dengi i Credit (9): 3-10. (In Russian)

Urban G., von Hippel E. 1988. Lead user analyses for the development of new industrial products. Management Science 34 (5): 569582.

van Renesse R. 1998. Optical Document Security. Artech House: Boston-London.

von Hippel E. 1986. Lead users: A source of novel product concepts. Management Science 32 (7): 791-806.

Initial Submission: June 30, 2020

Final Version Accepted: December 30, 2020

\section{Определения лидирующих рынков для леждународной индустрии производства банкнот}

\section{Г. В. Корнилов}

АО «Гознак», Россия

\section{A. В. Трачук}

«Высшая школа управления» Финансового университета при правительстве Российской Федерации, Россия

В статье представлено теоретическое исследование диффузии инноваций и исследуется роль фактора ориентации на ведущие рынки при внедрении инноваций на международных рынках 
продуктов и технологий для решения задач национальной безопасности с доминированием государственных закупок. Исследование основывается на данных, полученных в результате анализа инноваций в отрасли производства банкнот. Международный рынок банкнот, характеризующийся ограниченным числом покупателей (монопсония) и поставщиков (олигополия), является примером высокоинновационной отрасли, выполняющей задачу поддержания национальной безопасности - обеспечения наличного денежного обращения. Это глобальная отрасль, основной фокус инновационной активности которой сосредоточен на постоянной разработке новых защитных технологий, применяемых большинством центральных банков мира. Результаты анализа указывают на то, что фактор ориентации на ведущие рынки является одним из ключевых при принятии решения центральными банками в процессе выбора конкретных защитных признаков и технологий, используемых при производстве банкнот. При угрозе национальной безопасности географическое происхождение технологии играет меньшую роль, чем защитная ценность технологии сама по себе. Представляется, что фактор ориентации на ведущие рынки является особенностью диффузии инноваций в исследуемой отрасли и должен быть распространен на те сферы, в которых государство выступает в качестве единственного покупателя при ограниченном предложении, например в оборонной промышленности, исследованиях космоса, на отдельных фармацевтических рынках и др.

Ключевые слова: лидирующие рынки, индустрия производства банкнот, национальная безопасность, диффузия инноваций, денежное обращение.

JEL: G21, H76, L69, O33.

For citation: Kornilov G. V., Trachuk A. V. 2020. Identifying lead markets for the international banknote production industry. Russian Management Journal 18 (4): 497-524.

Статья поступила в редакцию 30 июня 2020 г. Принята к публикаиии 30 декабря 2020 г. 